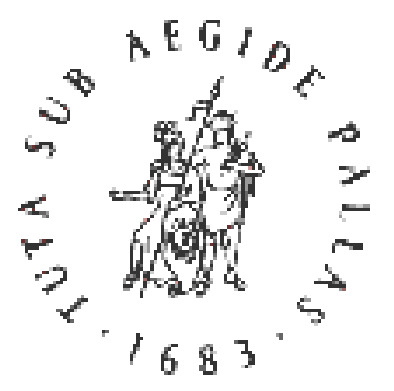

B R I L L

A Wonderful World: Folios from a Dispersed Manuscript of the "Nuzhat-Nāma" Author(s): Anna Contadini

Reviewed work(s):

Source: Muqarnas, Vol. 21, Essays in Honor of J. M. Rogers (2004), pp. 95-120

Published by: BRILL

Stable URL: http://www.jstor.org/stable/1523347

Accessed: $12 / 02 / 2012$ 20:21

Your use of the JSTOR archive indicates your acceptance of the Terms \& Conditions of Use, available at http://www.jstor.org/page/info/about/policies/terms.jsp

JSTOR is a not-for-profit service that helps scholars, researchers, and students discover, use, and build upon a wide range of content in a trusted digital archive. We use information technology and tools to increase productivity and facilitate new forms of scholarship. For more information about JSTOR, please contact support@jstor.org. 


\section{A WONDERFUL WORLD: FOLIOS FROM A DISPERSED MANUSCRIPT OF THE NUZHAT-NĀMA}

This paper is concerned with folios from a dispersed Persian manuscript of the Nuzhat-nāma-i 'Alä' $\bar{\imath}$ (the 'Ala'i Book of Pleasure) by Shahmardan b. Abi 'lKhayr Razi (fl. second half of the eleventh to early twelfth century), probably datable to the late sixteenth or early seventeenth century and possibly attributable to Qazwin. My acquaintance with this manuscript, leaves of which are held in at least seven different collections in Europe and the United States, goes back to 1989, when I first examined the ones in the Metropolitan Museum of Art and the Pierpont Morgan Library in New York. What was immediately clear at the time was that the generally accepted, if sometimes tentatively expressed, attributions-or perhaps, rather, the potential attributions-were incorrect: although dealing with animals and plants, these folios form part of neither a Qazwini 'Ajä'ib al-makhlūqāt nor a Manāfic text, nor do they belong to some vague natural history or unknown genre of herbal and bestiary. But it was not until 1991, when I was able to do some research on the Nuzhatnāma manuscripts in the Chester Beatty Library, that I arrived, as did Barbara Schmitz in relation to the leaves in the Pierpont Morgan Library, at the correct identification of the text. ${ }^{1}$

In her catalogue entry for the Morgan leaves, Schmitz also lists folios dispersed in other collections, but she does not include among them those in the Freer Gallery of Art in Washington, DC. What follows will therefore give pride of place to a presentation of the Freer folios (figs. 1-6), which to my knowledge have not been dealt with or published before. It will also present the folio in the Harvard University Art Museums, which was removed from its mount especially for research and photography so that I could study its verso side, which contains the picture of the peacock (figs. 7-8). The other folios, in particular those in the Prince Sadruddin Aga Khan Collection (figs. 9-14) and a selection of those in the Metropolitan Museum of Art in New York (figs. 15-18) will be taken into consideration when discussing date and provenance.
Included as an appendix is a catalogue of the material so far identified as belonging to the manuscript. This is meant to be preliminary to a more extensive study that will also include a translation of the text contained in the various folios. It is nevertheless pertinent to mention at this stage that there are strong textual similarities between these Nuzhat-nāma folios and the corresponding sections of the well-known M.500 in the Pierpont Morgan Library, which has been considered to be an Ibn Bakhtishu' Manāfic al-hayawān, produced in Maragha and dated between 1295 and 1299. This manuscript had always puzzled me as it has a cycle of miniatures quite distinct from those in the other manuscripts of the Ibn Bakhtishu' tradition, and the interference of a different literary source is also evident. In the introduction of the manuscript (fol. 3r) it is stated that the text is a translation from Arabic into Persian of the "Book of the Usefulness of Animals" (Kitāb manāic al-hayawān) and it is therefore understandable how it has come to be classified as an Ibn Bakhtishu' bestiary. Further, the textual similarity of the manäfi (usefulness) section of the text with that of the Ibn Bakhtishu' manuscripts provides evidence to support the association, as the translations below demonstrate. But despite this it is now clear, even if further investigation is required before the textual affiliations can be firmly established, that much of the text is not in the tradition of Ibn Bakhtishu' but, as may also be seen from the sample translated below, is rather to be related to the Nuzhat-nāma. ${ }^{2}$

\section{THE MANUSCRIPT}

So far I have been able to identify and study nineteen folios, which contain thirty-three miniatures. Some of these folios were in the possession of Demotte, ${ }^{3}$ although it is not known whether he held the complete manuscript.

Dispersed in the collections listed in the Appendix, the folios are all consistent in size and type of paper, 
and the miniatures present a consistent style of painting throughout, all obviously having being executed by the same painter (or possibly by a team working in the same atelier).

The script is a clear Persian naskh, in black ink with red rubrics. The date of the folios, on the other hand, is unclear, and the various suggestions for it-all relying, whether implicitly or explicitly, on stylistic comparisons-are reviewed below.

\section{AUTHOR AND TEXT}

The Nuzhat-nāma-i 'Ala' $\bar{\imath}$ is an encyclopedic Persian work written early in the twelfth century. Its title derives from the fact that its dedicatee, Abu Kalijar Garshasp, the Kakuyid prince of Yazd, had the laqab 'Ala' al-Dawla. Of its author, Shahmardan b. Abi 'l-Khayr Razi, what little is known has been gleaned from this and his other surviving work, the much earlier Rawdat al-munajjimin, written in 466 (1074). On the basis of their dates Lazard ${ }^{4}$ has suggested that Shahmardan may have been born ca. 440 (1048-49). Both works, written in periods of leisure, reflect the author's scientific bent, and the Nuzhat-näma in particular reveals a wide-ranging interest in natural phenomena. From the precision of his observations in various localities, it may be deduced that he probably lived mainly in central and northern Iran, and it was while in Jurjan and Astarabad that he composed a number of works including the Nuzhat-nama. The connection with Rayy suggested by the name Razi is reinforced by the fact that Shahmardan's teacher, Abu 'l-Hasan Nasawi, was active there, and he also appears to have been familiar with Khuzistan and Basra. At least in later life he held the post of secretary (dabīin), possibly with financial responsibilities. The date of his death is not known.

An edition of the text has been published, ${ }^{5}$ and Pertsch has given a full contents list in his account of a copy in the library in Gotha. ${ }^{6}$ The Nuzhat-nāma is largely based on, or adapted from, an earlier Arabic work by Shahmardan himself, who states that during an "idle" stay in Jurjan and Astarabad he composed a number of works, including an (Arabic) Kitāb al-bad $\bar{a}^{3} i^{c}$ that he then reworked, with sundry alterations and abbreviations but also with significant additions, to produce a more widely accessible Persian text. ${ }^{7}$

For the date that it was composed, we have in the first place evidence provided by the dedication, given in the introduction (muqaddima), to Abu Kalijar Garshasp, son of 'Ali, King of Mazandaran, son of Faramarz, son of 'Ala' al-Dawla Muhammad, son of Dushmanziyar.' Pertsch concluded that the Nuzhat-näma should be dated to around the middle of the eleventh century; but since the grandfather of the dedicatee, Faramarz, ruled between 433 and 443 (1041-51), his father 'Ali between 469 and 488 (1076-95), and Abu Kalijar Garshasp himself between 488 and about 513 (10761119), ${ }^{9}$ it must be dated somewhat later. This was confirmed by internal evidence spotted by Storey, who concluded that it could not have been composed before 475 (1082-83) or $477(1084-85),{ }^{10}$ while Blochet and Minovi opined that it "must have been written about 490 [1096]." "An even later date was proposed by Zabihallah Saba, on the grounds that the work draws on a book written by Abu Hatim Isfizari, who was still alive in 506. ${ }^{12}$ The crucial information that Shahmardan refers to this author as "the late Abu Hatim Isfizari" is supplied by Lazard. ${ }^{13}$ It may therefore be concluded that the Nuzhat-nama should be dated somewhere between 506 (1112) and the end of Abu Kalijar Garshasp's reign in 513 (1119). ${ }^{14}$

In his introduction, Shahmardan itemizes the contents of the ensuing twelve sections (maqālät), many with subdivisions $(f a s l)$, in considerable detail. They are grouped into two large blocks (qism), the first of which, echoing but also enlarging upon his summary account of the contents of his Kitāb al-bad $\bar{a}^{\prime} i^{c}$ as "characteristics, natures, uses, and various other sciences" (khavāss va tabä $\bar{i}^{\prime}$ va manäfic va chand 'ilm-i dīgar), is described as dealing with "the characteristics, uses, and natures of man and the animals: carnivores, wild animals and beasts, birds, reptiles and insects; trees, plants, stones, gems, and substances" (dar khavāss va manāfi va tabä $\bar{a}^{\prime} i^{c}$ $i$ mardum va hayavānāt az sibā va vuhüsh va bahă im va tuyūr va havāmm va hasharāt va ashjār va nabāt va ahjār va javāhir va ajsād). ${ }^{15}$

The dispersed folios so far identified all relate to this first block, and specifically to Sections 2 (quadrupeds, wild animals, and beasts), 3 (birds), 4 (reptiles and insects), and 5 (trees, seeds, and plants). Presumably, therefore, there were originally at the very least folios relating not only to the remaining contents of these sections but also to Section 1, on man. With regard to the parts following Section 5, nothing has yet come to light to indicate that the known folios were part of a manuscript of the complete work rather than just a segment thereof, but comparison with other illustrated manuscripts of the Nuzhat-namma suggests that this is 
likely, and that despite the more abstract subject matter of the second large block there would have been illustrations there too. ${ }^{16}$

\section{THE RELATIONSHIP TO THE IBN BAKHTISHU ${ }^{c}$ TRADITION}

Given the nature of the part of the text contained on the dispersed folios, it is not surprising that, despite the absence from it of material on trees and plants, links with the Ibn Bakhtishu' na ${ }^{c} t /$ manā $f^{c}$ tradition have been assumed, for the presentation of each animal follows a similar pattern: a description of its characteristics followed by a listing of the medicinal properties of various organs. ${ }^{17}$ Furthermore, evident textual similarities occur. In the description of the crane (kulang), ${ }^{18}$ for example, we find, even if reversed, the same two themes that are treated in the Kitāb na't al-hayawān in the British Library: ${ }^{19}$ the way the cranes take turns in keeping watch, and their equally egalitarian method of successively taking the lead as they fly in file. However, inspection of their respective medicinal $\left(\operatorname{man} \bar{a} f^{c}\right)$ sections reveals a radical lack of congruence. Thus only one organ of the crane-the gallbladder- is mentioned by Shahmardan, while in the $N a^{c} t$ we find an account of the various uses to which the brain, marrow, right eye, gizzard, testicles, and droppings can be put. ${ }^{20}$

The contrast is, admittedly, not always so marked: to take a simple instance, in both accounts of the duck its blood is thought to alleviate bladder pain. But such agreement need reflect no more than the general diffusion of a particular medical notion; as far as the relationship between texts is concerned it is the differences that are more significant, and, as we have seen with the crane, these can be extreme. To take a further example, we may compare the respective accounts given of the pheasant (tazaro), a bird that appears on one of the Freer folios. The edited text of the Nuzhat$n \bar{a} m a$, which is frequently at variance with that on the Freer folios, here has a compound heading: "francolin" (durräj) and "pheasant." In the Ibn Bakhtishu' Kitāb manāfi al-hayawān in the Escorial Library, ${ }^{21}$ the francolin receives a mention within the text on the pheasant, but there is no suggestion of a resemblance between the two, and the separate section on the francolin also has nothing in common with the compound account in the Nuzhat-nāma. For purposes of textual comparison the corresponding material in the so-called Ibn Bakhtishu' Kitāb manāfic al-hayawān in the Pierpont Morgan Library has been interposed between these two pas- sages (that of the Nuzhat-näma having been translated from the fuller edited text):

Nuzhat-nāma (verso side of folio in the Harvard Museum; Edition [see n. 4], pp. 158-59):

The francolin and the pheasant (durräj va tazarv). When the weather is fine and the wind is blowing from the north it grows fat, but with the south wind it becomes thin and in a poor state because its wings become so heavy that it cannot fly. When it does fly it emits a cry as if it is weary. The francolin has a crop and a broad, large stomach. In flight the francolin, pheasant, and partridge do not circle. They lay eggs on the ground and do not build nests. The chick that hatches from the egg, like the young of the chicken, puts its head to the ground, pecks grain, and finds its own food. The pheasant and the francolin are similar to each other and have a special characteristic, which is that before an earthquake happens they emit a cry, after which the earthquake takes place.

Pierpont Morgan Library Manā $f^{c}$ (in Persian), fol. 65r:

On the francolin (durrāj), its characteristics and uses. When the weather is fine and the wind blows from the north the pheasant (tazaro) and the francolin grow fat, but when the wind is from the south they become lean and ill, the reason being that the south wind makes their wings become so feeble that they cannot fly. The francolin, pheasant, and partridge lay eggs on the ground and do not make nests. When they hatch from the egg, like chickens they eat from the ground and obtain their own food. The pheasant and the francolin are similar to each other in nature. They have the characteristic that when there is going to be an earthquake they emit a call and a cry for help, after which the earthquake takes place. Among their uses are: their meat is similar to partridge-it constipates when eaten roasted. When their fat is dripped into the ear with seed oil, the pain is alleviated. Their eggs have the same properties as partridge eggs.

Escorial Manāfic (in Arabic), fol. 79r:

The pheasant (tadruj). The characteristic of this bird is cowardice. It does not rise high enough in flight to be seen, but rather conceals itself among trees, thorns, and thickets. It hatches numerous eggs like the chicken and partridge. [Its meat] is similar to chicken. Its eggs come next to francolin and partridge eggs for usefulness and excellent nutritive qualities.

Escorial Manāfic (in Arabic), fol. 75r:

The francolin (durrāj). Among its characteristics is that it 
loves greenery and water and therefore seeks out orchards and meadows. It forms couples like the dove, and the male broods upon the eggs with the female and guards them in the most thickly grown places, so that no animal can reach them. It has a beautiful voice. Its meat is similar to partridge meat, although it is wetter. Its characteristic is that it constipates, especially if eaten roasted. If its fat is melted together with pandanus oil and some of it is dripped into an ear that is aching, it alleviates the pain. The francolin's eggs are like partridge eggs for wholesomeness and nutritive value.

The description given by Shahmardan is thus longer than and quite different from that in the Escorial manuscript and the other Arabic Ibn Bakhtishu' manuscripts. However, neither account dwells on the medicinal aspect, in relation to which it remains to be observed that despite the divergences noted above, there can also be found instances of striking convergence that go far beyond the possibly accidental agreement about the properties of duck blood. For example, in their treatment of the uses of the crow (kalägh), both the British Library $\mathrm{Na} \mathrm{a}^{c} t$ and the Nuzhat-nama begin with a complicated preparation described in almost identical terms, while most of its applications are also the same: a crow is fed bread until its feathers fall out; it is then slaughtered and put in a vessel, its head plastered with mud, and buried in dung for forty-one days. When it is taken out there are black and white worms: these are left to die, and then three of each are taken and pounded with sesame oil. The resulting concoction is used to treat facial paralysis (only in the $N a^{c} t$ ) and leprosy, and if it is applied to the head the hair will never turn white, while if it is drunk it will cause the hair of the head to fall out and never grow again. For all this, clearly, there must be a common source. But thereafter the texts diverge again: the $N a^{c} t$ continues with another application of the whole bird and then proceeds to list the uses of its meat, blood, three unidentified parts, head, gallbladder, tongue, and eggs, while the Nuzhatnamma proceeds to deal with its eggs, blood, gallbladder, excrement, eye, fat, tongue, and heart; although there are some elements in common, the treatments discussed are generally different. It is, in short, clear that however much still needs to be done to sort out the tangled relationships between these and other related texts, the Nuzhat-nāma cannot be regarded as forming part of a linear Ibn Bakhtishu' tradition.

As we can see from the translated passages above, the Morgan Manāfic is much closer to the Nuzhat-nāma than to the Ibn Bakhtishu' book on animals. Not only are the two animals treated together in the Morgan manuscript and in the Nuzhat-nāma and separately in the Escorial (and the other) Ibn Bakhtishu' manuscripts, but the $n a^{c} t$ (characteristics) section is almost identical in both the Morgan manuscript and the Nuzhat-nāma and quite different from that in the Escorial manuscript. But that the relationship is nevertheless a complex one is shown by the fact that, unlike the Nuzhatnāma, the Morgan Manāji includes a manäfi section that closely resembles the one for the francolin in the Escorial manuscript.

This is a pattern that seems to recur for most animals, and the conclusion I must come to is that although, as already stated, there is a strong influx of Nuzhat-namma material in the Morgan manuscript, there is also a significant amount of material relatable to the Ibn Bakhtishu ${ }^{c}$ book on animals. This material is found in the manäfic sections, and we know (from explicit statements in the Kitāb na't al-hayawān in the British Library) ${ }^{22}$ that it is specifically these that come from Ibn Bakhtishu', in contrast to the na't sections, which relate to an Aristotelian tradition. It is probably because of this that the Morgan manuscript is identified in the introduction as a translation from Arabic into Persian of the "Book of the Usefulness of Animals."

\section{THE DATE OF THE MANUSCRIPT}

The miniatures of the dispersed folios have been attributed to different centers and dated from the fourteenth to the late sixteenth century. A fourteenth-century dating was proposed by Ettinghausen in 1959 and subsequently by Esin Atll, ${ }^{23}$ but they are outnumbered by the scholars advocating a fifteenth-century dating. These include Marteau and Vever, who suggested an attribution to Iran during the Timurid period, and called the work a treatise of "histoire naturelle"; Blochet, who attributed the miniatures in Boston specifically to Tabriz, thought that they were from a Qazwini 'Ajā'ib al-makhlūqāt, and dated them to about 1460; Riefstahl, who attributed a folio now in the Pierpont Morgan Library to Tabriz, ca. 1480, and thought it was from a Qazwini ' $A j \bar{a}$ ' $i b$ al-makhlūqāt; Welch, who thought they were from a late-fifteenth-century Qazwini 'Ajā'ib al-makhlūqāt; and Coomaraswamy, who thought the folios in Boston were probably from a Manāfic al-hayawān of the fifteenth or sixteenth century. A sixteenth-century dating-indeed, a specifically late-sixteenth-century dating-was proposed for the folios in the Pozzi Collection by Robinson, who attributed them to a provincial Qazwin school 
and thought that they were part of a Qazwini 'Ajä'ib al-makhlūqät. More recently the same attribution and date (1575-85) have been given (with the right identification of the text) by Schmitz, who cites in support comparisons with a Tuhfat al-gharä'ib attributed to Qazwin and dated Shawwal 984 (December-January 1576-77). ${ }^{24}$ It is precisely such comparative evidence that needs now to be reviewed, beginning with the script and going on to a more detailed consideration of stylistic and motivic data.

\section{THE SCRIPT}

It is worth making the initial point that whereas miniatures may be studied in some detail for dating purposes, the nature of the surrounding script is liable to be neglected. In the present case we should at least note the contrast between the Qazwini manuscript referred to by Schmitz, which is in a fully developed nasta $\bar{l} \bar{q}$, and our manuscript, which is in naskh. For this to have any implications for the dating of the latter, though, we would need to be able to do more than simply refer to the chronological frame supplied by the approximately datable shift from one to the other, even if appeal to this has on occasion been made, at least implicitly. There are, for example, two illustrated Nuzhat-nāma manuscripts in the Chester Beatty Library, of which one (probably produced in Isfahan), in nasta $l \bar{q} q$, is dated 1007 (1599). The other is in naskh, and it is primarily on the basis of "the character of the script" that Blochet and Minovi arrive at a suggested date of ca. $1400 .{ }^{25} \mathrm{But}$ for a Persian manuscript, it is in fact hazardous to rely on the use of naskh alone to support a dating to the earlier rather than the later part of the fourteenth-tosixteenth-century period. The problem is that although the use of nastac li $q$ for Persian manuscripts may well have become the norm by the sixteenth century, there are cases, such as a copy of Kashifi's Anvār-i suhayli, dated 13 Safar 1002 (November 8, 1593) and possibly produced in Qazwin or Isfahan, that demonstrate the continued use of naskh in the late sixteenth century. ${ }^{26}$ In the present case, therefore, the simple identity of the script yields at best a weak probability. But this is not to say that the nature of the script deserves to be disregarded: it is to be hoped that future research, at least beyond the stable calligraphic orthodoxies maintained for the copying of the Qur'an, will be able to establish for each major script style objective criteria enabling some chronological distinctions to be made. Until then, in order to narrow the time scale with any confidence, we must appeal to other types of evidence, to be derived most obviously from a comparative study of stylistic features and techniques of representation.

\section{THE MINIATURES}

Although in most cases the grounds for the datings offered above are not made explicit, it can safely be assumed that they largely rely on specific features, whether of motif or technique, for which parallels can be found elsewhere. Thus to support a fourteenth-century dating one might adduce similarities with features of animal and plant illustrations in thirteenth- and fourteenth-century Arabic manuscripts-for example, the use of gold to mark some parts of the body, or, more vaguely, certain landscape elements that can be paralleled in Kalila wa Dimna and Qazwini manuscripts of the Jala'irid and Muzaffarid periods. (It may be noted that the Nuzhat-nāma manuscript in the Chester Beatty Library dated to around 1400 by Blochet and Minovi on the basis of script also exhibits features relatable to Jala'irid material, but it is difficult to regard it as relevant to the present discussion, for its miniatures are quite different in style from those of our dispersed folios.) Likewise, the fifteenth-century dating preferred by most authorities could have been prompted by certain similarities in the depiction of animals to be seen, for example-as Schmitz has already pointed out-in a Qazwini Tuhfat al-ghara $\bar{a}^{2} i b$ of the second third of Rabic II 897 (mid-February 1492) in the Österreichische Nationalbibliothek in Vienna. ${ }^{27}$ As for the late-sixteenth-century attribution, Robinson does not give explanations or cite comparative material, but Schmitz cites another Qazwini Tuhfat al-ghara $\bar{a} i b$ in the Österreichische Nationalbibliothek, in this instance dated Shawwal 984 (December-January 1576-77) and attributed to Qazwin, on the grounds that the landscape features are similar. However, although there is a generic similarity to some of the flowers and plants, the parallels are not very close, and other features such as clouds and, more importantly, the animals themselves, are rather different. Similarly, it would be misleading to support a fifteenth-century dating by referring to the presence of the motif of small, running clouds that occurs during the Timurid period ${ }^{28}$ without noting that in our miniatures the clouds no longer have the marked spiral-and-ribbon quality that associates them closely with Chinese models.

It will be clear from this review that, as was only to be expected, certain points of reference can be found 
for features present in the Nuzhat-nàma miniatures in a variety of manuscripts produced during the fourteenthto-sixteenth-century period. But as the whole concept of these manuscripts is different, so is the composition of their miniatures, and the comparisons they provide are frequently confined to secondary features, with the result that they are seldom conclusive, offering as they do general resemblances confined for the most part to stock iconographical elements such as bunches of grass and flowers. There are consequently no common features sufficiently striking to point unequivocally to a particular time and place, and a major element of the importance of the miniatures in these dispersed folios resides precisely in the fact that they embody a particular stylistic synthesis that has no very close relatives surviving elsewhere. The need, therefore, is not to suggest a dating on the basis of individual features, and especially not ones marginal to the composition as a whole, but as far as possible to draw strands together and give greater weight to core elements and accordingly to pay particular attention to the composition and depiction of the animals and plants-especially the flowers-and the palette used.

Viewed in this light, the few elements that can be related to scientific Arab and Persian painting of the thirteenth and fourteenth centuries (for example, the idea of marking out parts of the body in gold, and the fact that the page and the miniatures are not framed), and the few landscape features that can be paralleled in Timurid material (in particular the bunches of leaves and round flowers), assume less importance than the fact that the general rendering of the animals, trees, and flowers is far more vivacious and naturalistic than any we find during the Timurid or earlier periods, in which there is marked stylization. This is true of the postures and movements of the animals as well as of the attention to detail in the depiction of their bodies, fur, plumage, eyes, mouths, etc.

The repertoire of flowers is rich. In addition to rocks and little flowers with single bigger round ones in the middle-a motif that begins to appear in the fifteenth century-we have carnations, irises, mallows, anemones, violets, poppies, and buds of various kinds, still enclosed in their light brown or green spiky leaves (see figs. 10 and 16). Some of these, such as the iris and the mallow, already appear in the repertoire of the fifteenth century, but those in our folios are fleshier and more naturalistically rendered, suggesting perhaps an acquaintance with, or an indirect influence from, European botanical studies.
Such a possibility is reinforced by the fact that some of our miniatures include the characteristic botanical motifs of insects or butterflies flying above flowersmotifs usually positioned at an upper corner, as in the miniature of the pheasant in the Freer (fig. 2), the ass and the wild ass in the collection of Prince Sadruddin Aga Khan (figs. 13, 14), the unicorn in the Metropolitan Museum, and the buffalo in the Morgan Library. In three cases-the goat in the Morgan, the mountain cow/stag in the Prince Sadruddin Collection (fig. 12), and the bull in the Metropolitan (fig. 16)-we find two insects, one a fly or bee and the other a butterfly in profile.

Further pointers towards a later date are provided by the palette and the brush strokes. The palette is quite rich, with a predominance of colors that one would associate with the late Safavid period, in particular orange and purple. The small running clouds in the upper part of the miniatures are rendered mostly in gold but also in purple, and the insects, when present, are also in gold. Although animals and plants are often partially outlined with black ink, major parts of the miniatures, especially leaves and flowers, have been drawn without a contour. The brush strokes are free, with a juxtaposition of thicker and thinner strokes and more watery strokes in the same color used to create depth and suggest differences in thickness. Although the animals are usually without contour lines, some of their parts have been outlined in black, a practice typical of the late sixteenth and early seventeenth centuries. ${ }^{29}$

For the animal depictions comparative material from this period is provided, for example, by the lion on a folio attributed to Qazwin or Mashhad, ca. 1560, in the Harvard University Art Museums, ${ }^{30}$ or even the lion on a famous album page by Sadiqi Beg of ca. 1605 (also in the Harvard Museums), ${ }^{31}$ which has a similar posture, muscular body, open mouth outlined in blackwhich in our folio (fig. 15) does not seem to have been added later-dangling tongue, and expressive eye. The shape and design of the tail of the peacock in the Harvard folio is reminiscent of other peacocks' tails, such as the one depicted in a Qazwini 'Ajä'ib al-makhlūqāt in the John Rylands Library dated 12 Dhu 'l-Hijja 1041 (June 30, 1632). ${ }^{32}$ Similarly, the "two rocks and flowers" motif in our manuscript is fully developed in material that comes from the period of the late sixteenth to early seventeenth century, exemplified by the Sadiqi Beg Anvār-i suhayli of 1593, in which there is a parallel repertoire of flowers, at times treated in a rather similar way. In the Sadiqi Beg manuscript similarities can 
also be discerned in such animal features as the multicolor plumage of certain birds represented in motion, the expressive eyes of horses and donkeys and their characteristic dropped lower jaws, and the shape and stance in the depiction of the bull. Other elements of the manuscript, however, are quite different; clouds and rocks, for example, retain a much closer affinity with a Chinese manner of rendering. Perhaps nearer, in terms of the "two rocks and flowers" motif and the treatment of the horses with "made up" eyes and lower jaws opened at almost right angles to their heads, is the Shāhnāma of ca. 1604 in the British Library. ${ }^{33}$

As for the flower-and-insect motif, we really have to turn to seventeenth-century material to find parallels, albeit in tinted drawings or border designs rather than in fully colored paintings. A relatively early instance is the early-seventeenth-century drawing in the British Library of a youth digging, ${ }^{34}$ which has a flying bird and an insect-possibly a butterfly-at the upper left of the page. An almost identical butterfly is found twice in a tinted drawing, also datable to the early seventeenth century, in the Prince Sadruddin Aga Khan Collection (M. 273); its subject is an artist seated with his drawing board. Later in the century flowers and flower-and-insect motifs are rendered in a way that is much closer to European models, as in a Dioscorides De Materia Medica in St. Petersburg ${ }^{35}$ (a Persian translation by Ghiyath al-Din Muhammad Radwi) dated Jumada II 1068 (March 1658) and probably produced in Isfahan. This contains a variety of depictions of plants and flowers in accordance with the Dioscorides text; the source for these is more evidently to be located in botanical drawings. ${ }^{36}$

The conclusion to be derived from such discussion is that the Nuzhat-nāma miniatures are likely to represent either a late-sixteenth-century production, or, more probably, one of the early seventeenth century. We need more miniatures from our dispersed manuscript to come to any firmer judgment; particularly desirable would be a human figure, which might help resolve the problems of attribution, not only of date but also of place.

Although an attribution to Qazwin seems plausible, the rather individual nature of the miniatures makes it impossible, as the above discussion demonstrates, to find conclusive parallels, so that other centers of production cannot be excluded. There are illustrated manuscripts of this period attributed to Shiraz, for example, and manuscripts of a scientific nature dating from the late sixteenth century that have been attributed to
Baghdad, such as a Qazwini 'Ajä'ib al-makhlūqāt in the Institute of Oriental Studies in St. Petersburg (D 370), dated 988 (1580). ${ }^{37}$ However, given the present limited state of knowledge, a review of the evidence for manuscript production in Baghdad or other provincial centers might conceivably produce a list of more or less plausible alternatives to Qazwin but could hardly point to the particular milieu in which the Nuzhat-näma was produced, the task being exacerbated by the difficulties posed by the surviving miniatures, which, apart from being of good quality in terms of drawing, details, spatial arrangement, and colors, are so far unparalleled and unique.

\section{THE FREER FOLIOS (FIGS. 1-6)}

There are three folios, two of them fragmentary, in the Freer Gallery; they feature six miniatures in total: two of birds and four of plants. Their general characteristics, also common to all the other dispersed folios, include unframed text areas and miniatures and paper of relatively thick, creamy woof but with visible chain lines, of a good but rather coarse quality common in the Safavid period. The margins have been trimmed. The text is in black ink with red rubrics for the names of the animals or plants.

The complete folio (inv. no. 47.21) has a miniature depicting the duck (murghābi $)$ on the recto (fig. 1) and one of the pheasant (tazaru) on the verso (fig. 2). The page measures $24.4 \mathrm{~cm}$ (height) $\times 16 \mathrm{~cm}$ (width) (for all measurements henceforth, height precedes width). The text block is $18.5 \times 10.8 \mathrm{~cm}$; there are sixteen lines of text on both recto and verso. The miniature of the duck on the recto is $4.8 \times 10.5 \mathrm{~cm}$; that of the pheasant on the verso is $4.8 \times 10.8 \mathrm{~cm}$.

The text concerning the duck (murghā $b \bar{l}$ ) begins at the fourteenth line, the preceding material belonging to the section on the cock and hen. The text for the duck continues on the verso, where, at the fifth line, the pheasant (tazary) is introduced. The text for the pheasant covers seven lines, and then the swallow (khuttāaf) is introduced, but we do not have a miniature for this bird.

The duck is multicolored and is set in a pool with its wings spread, as if splashing about in the water. The color of the water is silver, which now appears gray, and the waves are indicated by thin black lines. The curved outline of the pool is surrounded by earth and grass on which are rocks and flowers. In the upper background there are small gold and purple clouds. The colors are 


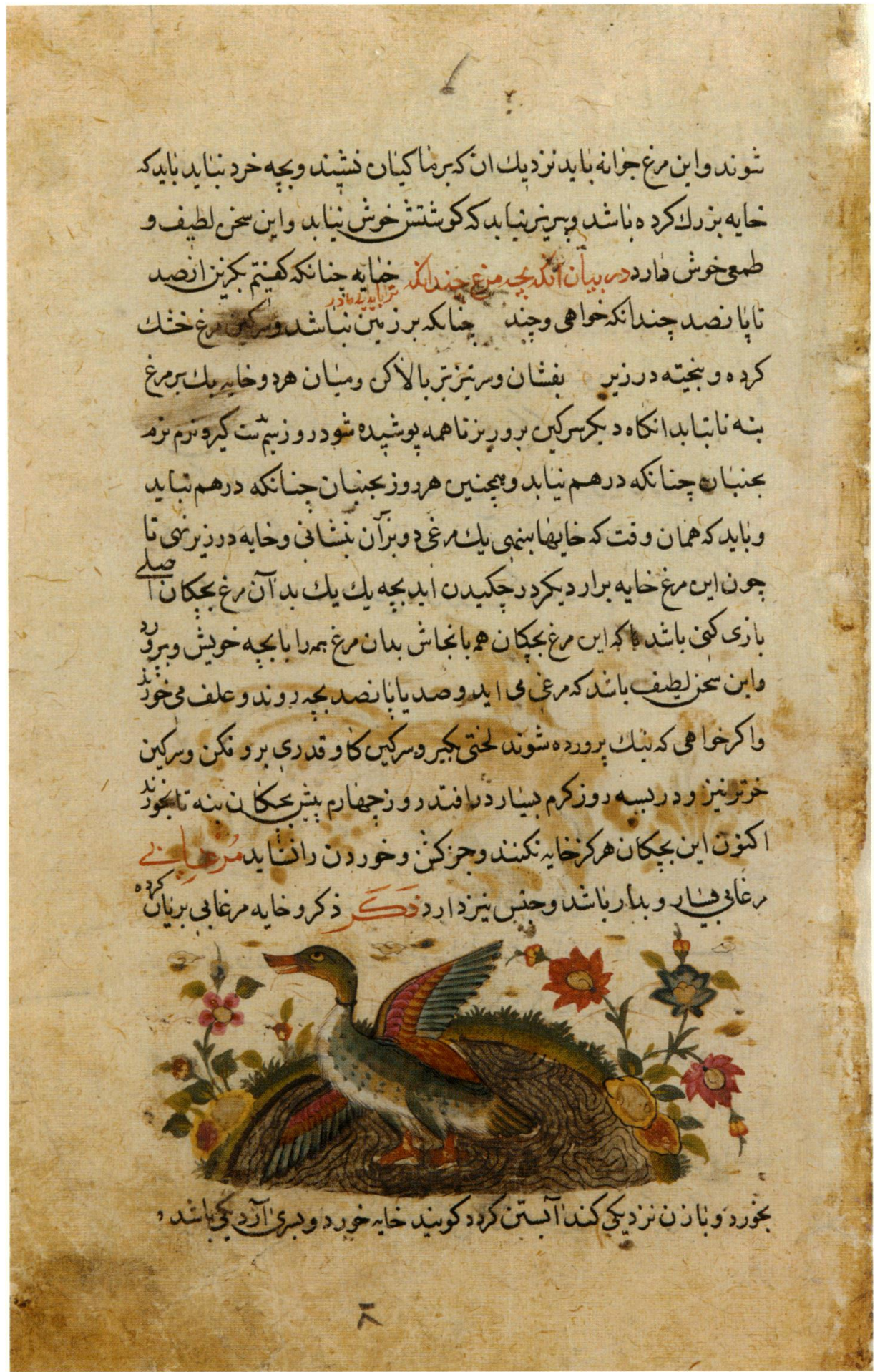

Fig. 1. Duck (murghābin), from the dispersed Nuzhat-nāma, Freer Gallery of Art, 47.21 (recto). Page 24.4 x $16 \mathrm{~cm}$, miniature $4.8 \times$ $10.5 \mathrm{~cm}$. (Photo: courtesy of the Freer Gallery of Art, Smithsonian Institution, Washington, DC) 


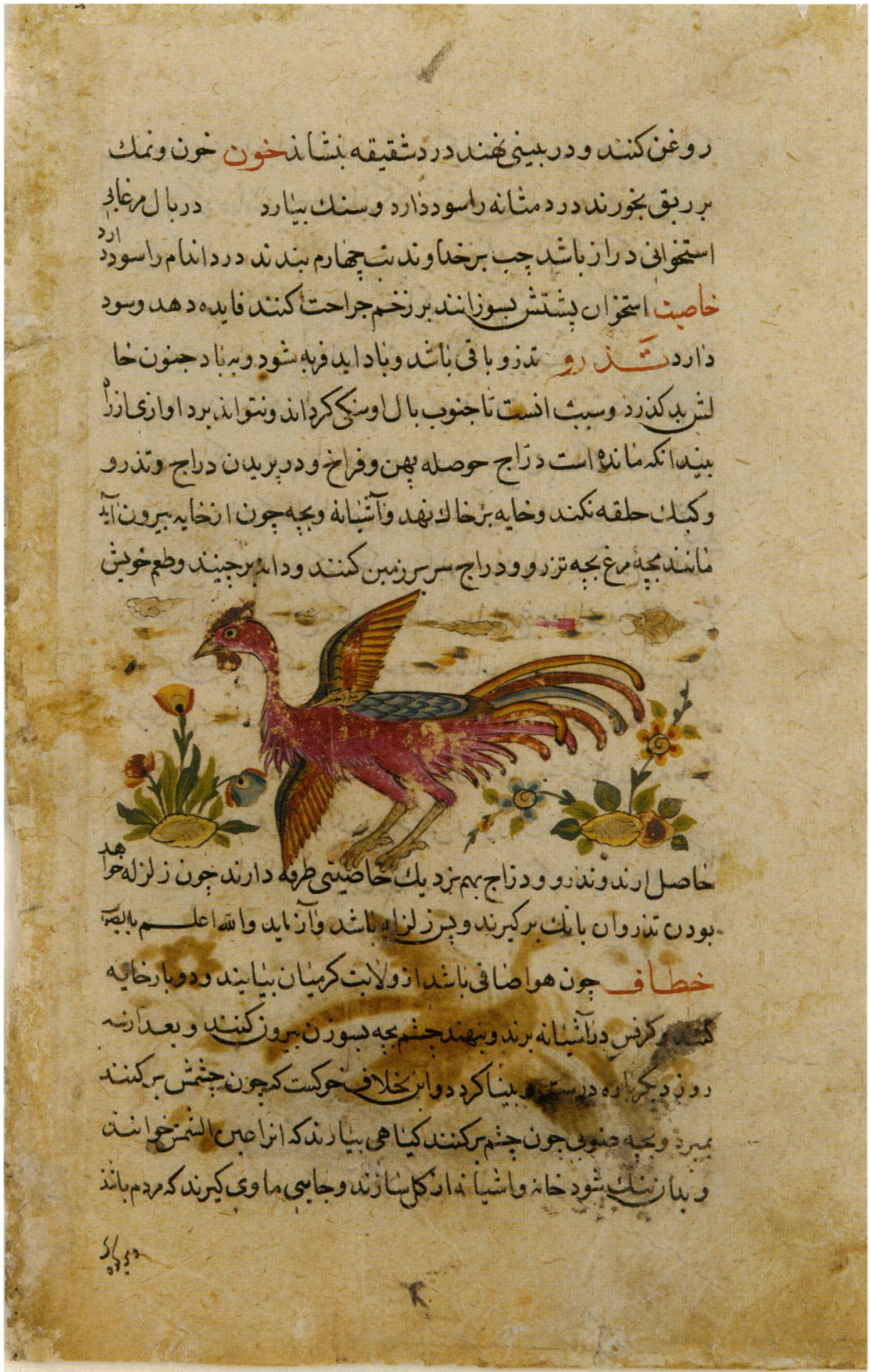

Fig. 2. Pheasant (tazarv), from the dispersed Nuzhat-nāma, Freeer Gallery of Art, 47.21 (verso). Note the flying insect in the right upper corner. Miniature $4.8 \times 10.8 \mathrm{~cm}$. (Photo: courtesy of the Freer Gallery of Art, Smithsonian Institution, Washington, DC) 


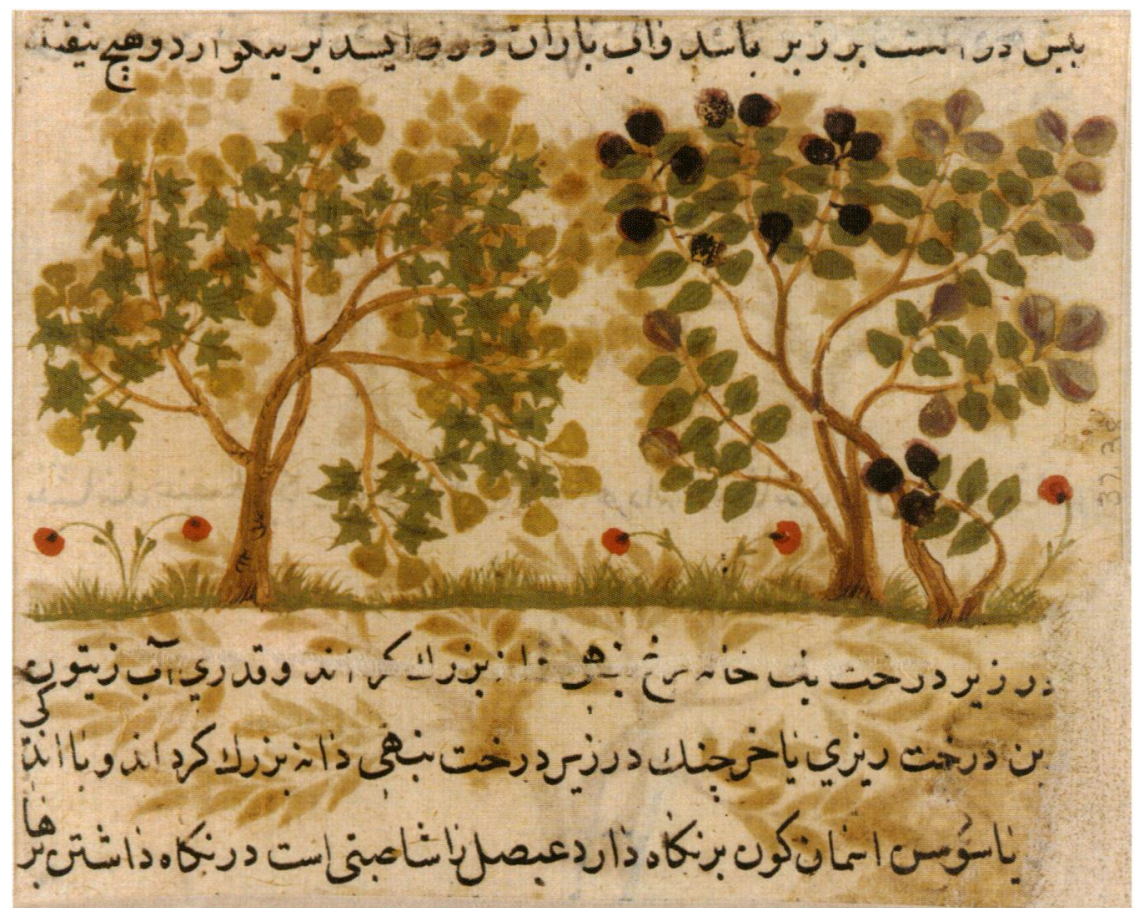

Fig. 3. Fragmentary folio with fig trees (anjīr), from the dispersed Nuzhat-nāma, Freer Gallery of Art, 37.38 (recto). Page $9.5 \mathrm{x}$ $11.5 \mathrm{~cm}$, miniature $5.5 \times 10.8 \mathrm{~cm}$. (Photo: courtesy of the Freer Gallery of Art, Smithsonian Institution, Washington, DC)

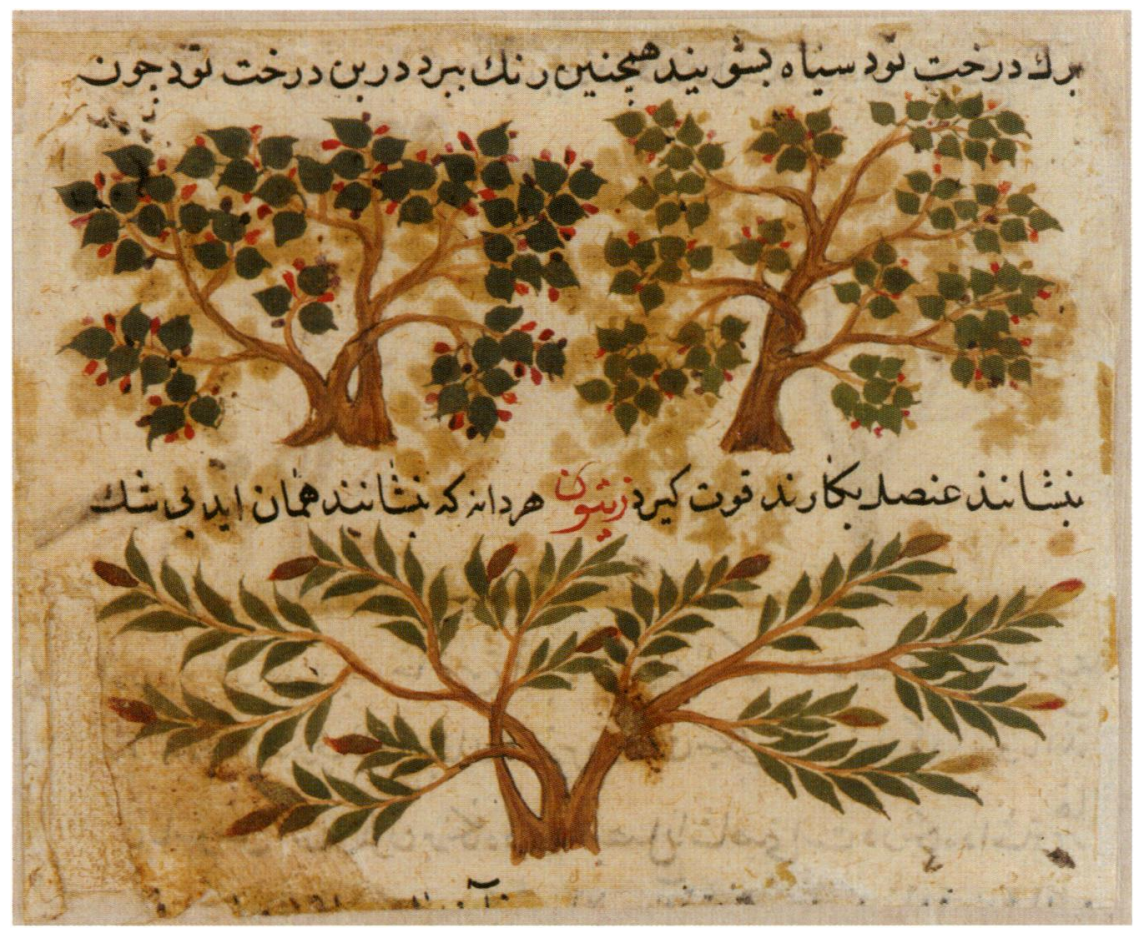

Fig. 4. Fragmentary folio with mulberry trees $(t \bar{u} d)$ and olive tree (zaytün) from the dispersed Nuzhat-näma, Freer Gallery of Art, 37.38 (verso). Miniatures $4 \times 10.2 \mathrm{~cm}, 3.8 \times 10.5 \mathrm{~cm}$. (Photo: courtesy of the Freer Gallery of Art, Smithsonian Institution, Washington, DC) 


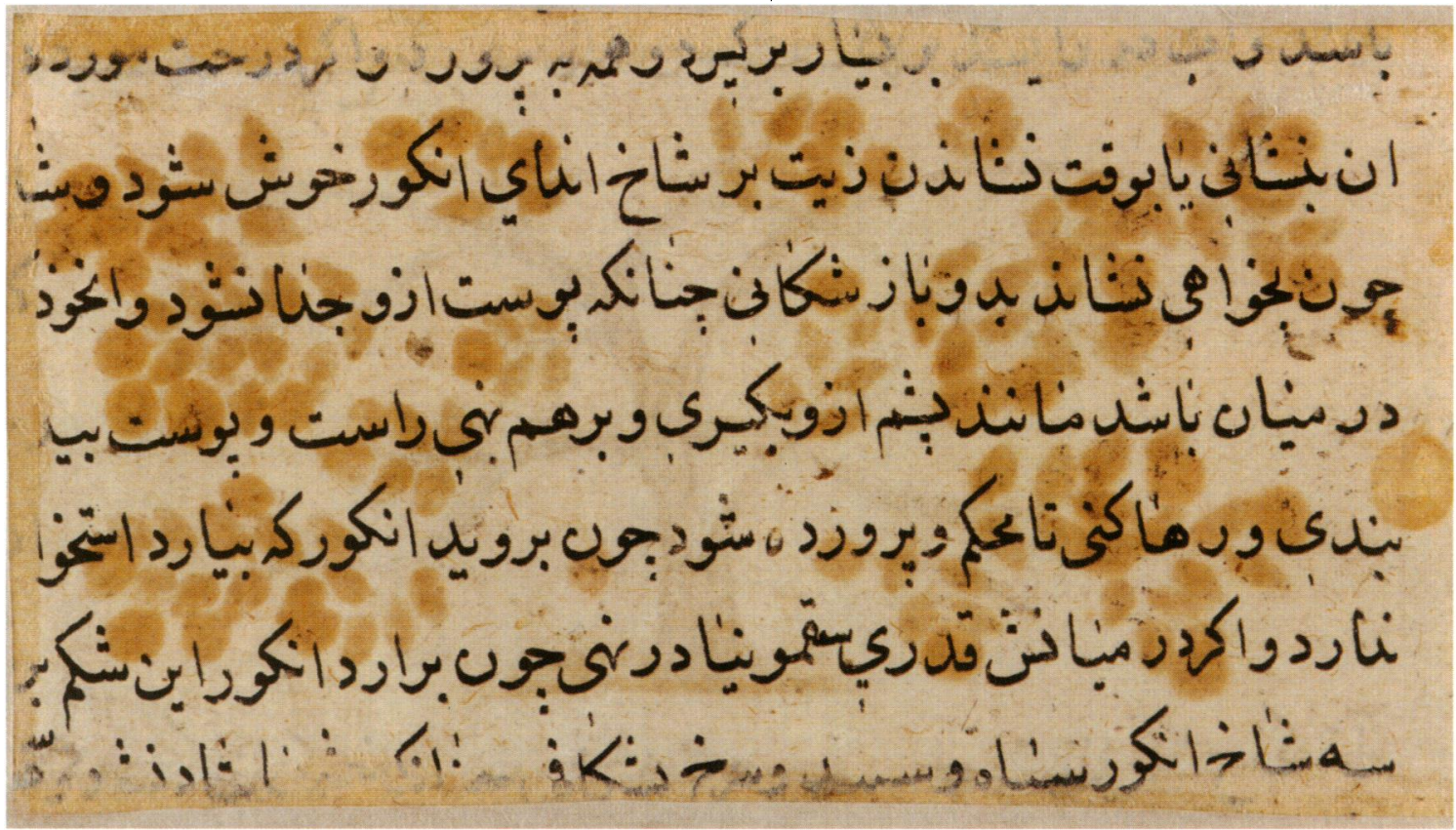

Fig. 5. Fragmentary folio with text concerning the grapevine (razangūr), from the dispersed Nuzhat-näma, Freer Gallery of Art, 37.39 (recto). Page 6.5 x $11.8 \mathrm{~cm}$. (Photo: courtesy of the Freer Gallery of Art, Smithsonian Institution, Washington, DC)

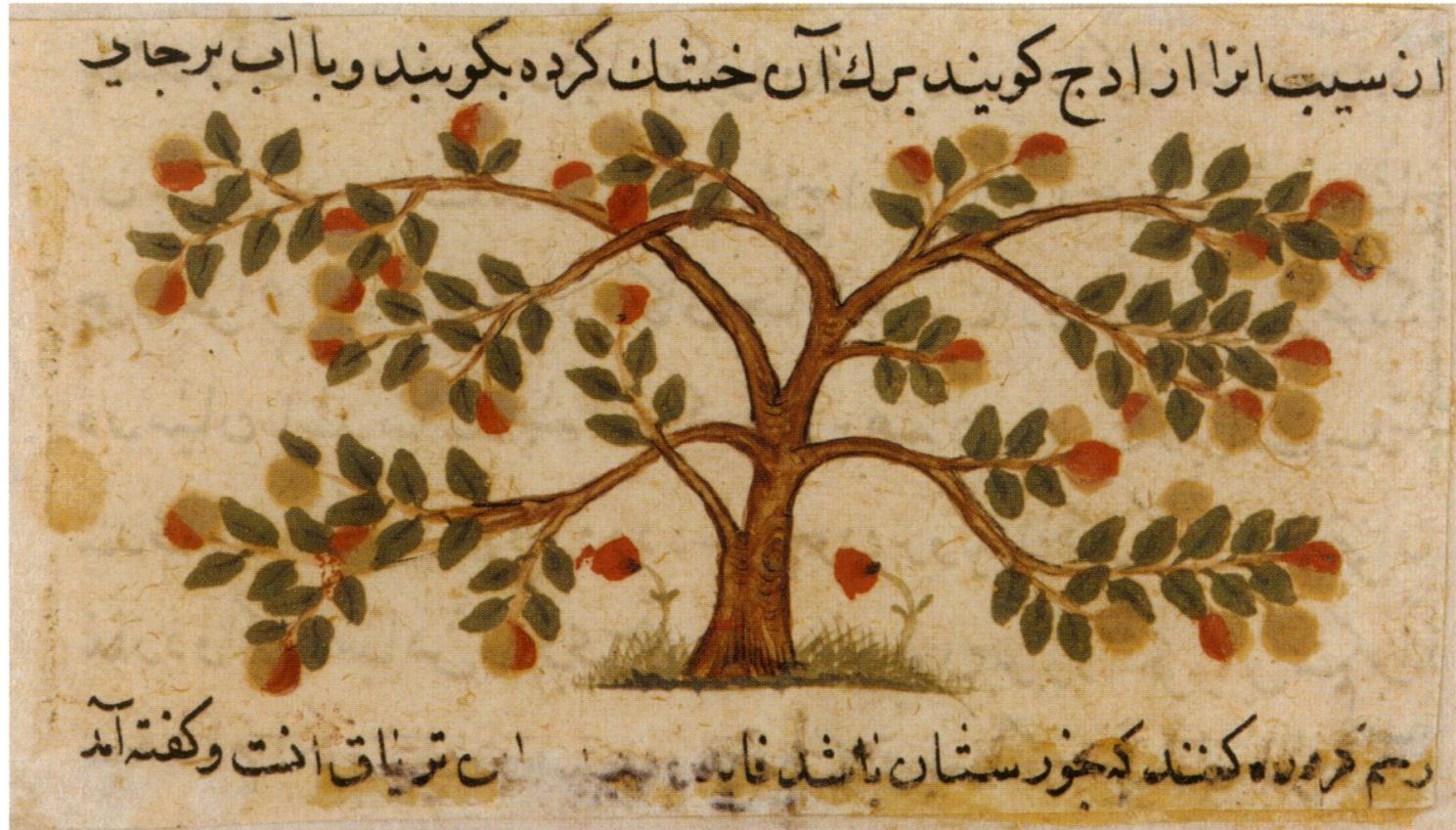

Fig. 6. Fragmentary folio with apple tree (sīb), from the dispersed Nuzhat-nāma, Freer Gallery of Art, 37.39 (verso). Miniature $4.5 \times 9.8 \mathrm{~cm}$. (Photo: courtesy of the Freer Gallery of Art, Smithsonian Institution, Washington, DC) 
still bright, with a palette that includes violet, green in various shades, orange, red, black, yellow, silver, and gold.

The pheasant is also multicolored; it is positioned with its wings spread as if it had just landed on the ground. The miniature includes rocks from which flowers sprout on either side; little clouds and a flying insect appear at the top right. The comments made about the colors for the representation of the duck are also valid here; the colors of that miniature have left a slight discoloration on this side of the folio.

The two fragmentary folios (inv. nos. 37.38 and 37.39) feature pictures of trees. They are now remargined and mounted together. It is interesting to note as a general characteristic that the trees, like the animals, have black outlines only in certain areas, in their case usually parts of the trunks, where there are only little black touches here and there, while there are none on the leaves. Also noteworthy in the tree pictures is the absence of gold. The trees have spreading crowns and branches that descend almost to the ground. Each tree is differentiated in its foliage and the shape of its fruit, and in some cases (as with the flowers) the rendition is fairly naturalistic.

37.38r (fig. 3): The recto side of this fragmentary folio shows one line of text, then a representation of two fig trees $($ anji $r)$ side by side, and then three lines of text. There are no red rubrics. The trees have brown trunks and green leaves. The one on the left has pale green fruit; the one on the right has darker leaves and dark purple fruit. Beneath them is a strip of grass with red poppies; the grass is rendered as single blades, not outlined. Measurements of the page are $9.5 \times 11.5 \mathrm{~cm}$. The miniature measures $5.5 \times 10.8 \mathrm{~cm}$.

37.38v (fig. 4): The verso of the fragment has one line of text below which two mulberry trees $(t \bar{u} d)$ are depicted side by side. They have brown trunks, green leaves (the one on the left being darker), and red fruit. Below this illustration is another line of text containing, in red, the title of the olive tree, zaytūn. The tree depicted beneath has a brown trunk with green and appropriately lanceolate leaves. The page measures 9.5 $\mathrm{x} 11.5 \mathrm{~cm}$; the top miniature is $4 \times 10.2 \mathrm{~cm}$; the bottom is $3.8 \times 10.5 \mathrm{~cm}$.

37.39r (fig. 5): On this recto side of the smaller fragment are seven lines of text, no red rubrics, and no miniatures. However, the text is concerned with the grapevine (razangūr). Stains of the fruit depicted in the illustration on the verso are visible on this side. The fragment measures $6.5 \times 11.8 \mathrm{~cm}$.
$37.39 \mathrm{v}$ (fig. 6): Apple tree $(s \bar{\imath} b)$. On this verso is one line of text, below which is the miniature of the apple tree and, following that, a second line of text. There are no red rubrics. The tree has a brown trunk with some black outlines, green leaves, and apples that are red, cream-colored, or a combination of red and cream. A strip of grass appears only in the area around the trunk and two flowers. The miniature measures $4.5 \times 9.8 \mathrm{~cm}$.

\section{THE HARVARD FOLIO (FIGS. 7-8)}

The page measures $24.5 \times 16 \mathrm{~cm}$. The text area and the miniatures are not framed (as is also true of all the other folios). On the recto the text area is $18.5 \mathrm{x}$ $11 \mathrm{~cm}$ with 16 lines of text; the miniature of the crow measures $4 \times 10.6 \mathrm{~cm}$. The text area of the verso is $18.7 \times 11 \mathrm{~cm}$, with 15 lines of text; the miniature of the peacock measures $5 \times 10.5 \mathrm{~cm}$. For the paper and color palette of these miniatures, see comments about the Freer folios above. On the verso, the page has been repaired on the left side.

Recto, 1919.0129.0002 (fig. 7): the text is concerned throughout with the crow (kalägh) and surrounds the image of the crow, which is placed below the first three lines of text.

Verso, 1919.0129.0001 (fig. 8): the treatment of the crow continues for nine lines and into the tenth, where the text on the general characteristics of the peacock begins, introduced by the title $t \bar{a}^{3} \bar{u} s$ in red. The image of the peacock is at the bottom of the page. There is a much later inscription in the upper margin, which seems to be a poetic verse unrelated to the text of the manuscript.

The Crow is depicted as a black and gray bird; touches of gold are added around its eye, on the clouds, on a couple of stones, and occasionally on the bigger flowers.

The miniature of the peacock is colorful, and the bird is depicted in the act of feeding, with its right leg raised and its head bending towards the ground. The area of its breast is slightly damaged. There are touches of gold on the clouds, on the eyes of the peacock's tail, and on the rocks and flowers. 


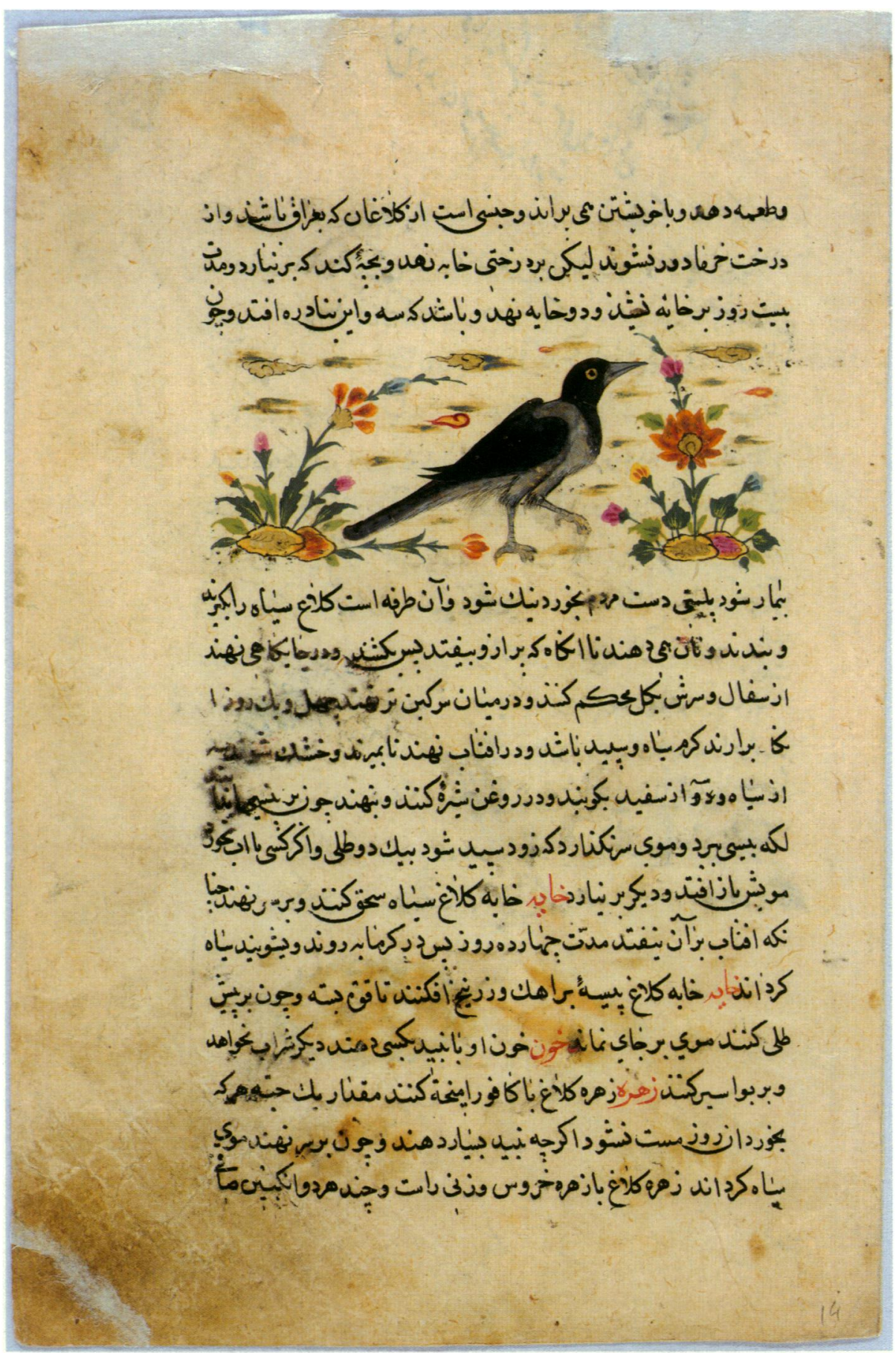

Fig 7. Crow (kalāgh), from the dispersed Nuzhat-nāma, Harvard University Art Museums, 1919.0129.0002 (recto). Page 24.5 x 16 $\mathrm{cm}$, miniature $4 \times 10.6 \mathrm{~cm}$. (Photo: courtesy of the Arthur M. Sackler Museum, Harvard University Art Museums, Cambridge, MA, Bequest of Hervey E. Wetzel) 


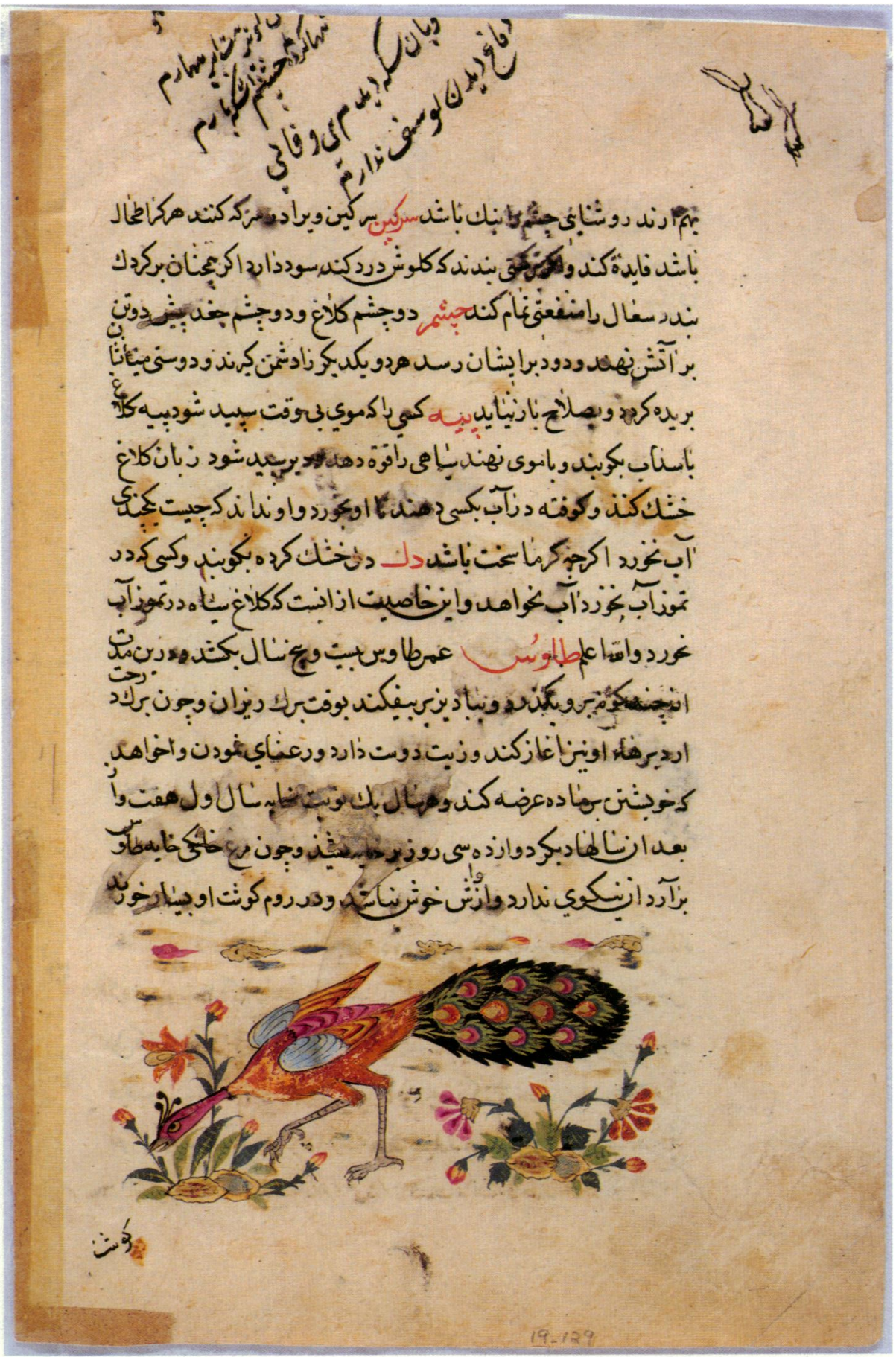

Fig. 8. Peacock $\left(t \bar{a}^{3} \bar{u} s\right)$, from the dispersed Nuzhat-nāma, Harvard University Art Museums, 1919.0129.0001 (verso). Miniature 5 x $10.5 \mathrm{~cm}$. (Photo: courtesy of the Arthur M. Sackler Museum, Harvard University Art Museums, Cambridge, MA, Bequest of Hervey E. Wetzel) 


\section{APPENDIX I: \\ PRELIMINARY LIST OF EXTANT FOLIOS}

Freer Gallery of Art, Washington, DC: three folios (two fragmentary), six miniatures (figs. 1-6)

47.21

recto: duck, murghābi

verso: pheasant, tazaro

37.38 (fragmentary)

recto: two fig trees, anjīr

verso: two mulberry trees, $t \bar{u} d$, and the olive tree, zaytūn

37.39 (fragmentary)

recto: text of grapevine, razangūr, no miniature

verso: apple tree, $s \bar{\imath} b$

Harvard University Art Museums, Arthur M. Sackler Museum, Cambridge, MA: one folio, two miniatures (figs. 7-8)

recto (inv. no. 1919.0129.0002): crow, kalāgh

verso (inv. no. 1919.0129.0001): peacock, $t \bar{a}^{3} \bar{u} s$

Bibliography: G. Marteau and H. Vever, Miniatures persanes tirées des collections de MM. Henry d'Allemagne, Claude Anet [et al.], et exposées au Musée des arts décoratifs, juin-octobre 1912 (Paris, 1913), 2 vols., vol. 2, pl. 59, no. 71 (the peacock). Attribution: from "un livre d'histoire naturelle arabe," Timurid period, Persia, fifteenth century.

Collection of Prince Sadruddin Aga Khan: five folios, six miniatures (figs. 9-14)

Ir. M. 16

recto: miniature of the mountain goat, buz $k \bar{u} h \bar{\imath}$ (fig. 9)

verso: continuation of text on the mountain goat and then title for the camel (shutur), but no miniature

Ir. M. 16/A

recto: miniature of the owl, jughd (fig. 10)

verso: miniature of the kite, zaghan (followed by title of the crow, kalägh) (fig. 11)

Ir. M. 16/B

recto: text with title of the mountain cow/stag, gā $k \bar{u} h \bar{\imath}$

verso: miniature of a mountain cow/stag and continuation of text (fig. 12)

Ir. M. 16/C

recto: text with title of the ass, khar

verso: miniature of the ass and continuation of text (fig. 13)
Ir. M. 16/D

recto: title and miniature of the wild ass, khar-i vahsh $\bar{\imath}$ (fig. 14)

verso: text on the wild ass, and then title of the bull, $g \bar{a} v$.

Bibliography: A. Welch, Collection of Islamic Art, Prince Sadruddin Aga Khan (Geneva, 1972-78), 4 vols., vol. 1, pp. 122-27. Attribution: from a Qazwini 'Ajä'ib al-makhlūqāt, late fifteenth century. Two miniatures illustrated: Ir. M. 16/A ("a blue-gray bird of prey") and Ir. M. 16/B ("stag").

Metropolitan Museum of Art, New York: four folios (one fragmentary), nine miniatures (figs. 15-18)

13.160.7

recto: miniature of the bull, gāv (fig. 16)

verso: text of the bull

13.160 .8

recto: miniature of the lion, shīr (fig 15)

verso: text of the lion

13.160 .9

recto: three plants: hesperis tristis (?), mans̄ür; iris, sūsan; anemone, āzararyūn (fig. 17)

verso: two plants: purple amaranth, bustān afrūz; watermelon, kharbuza (fig. 18)

1975.192.11

recto: unicorn, jarīsh

verso: steinbok, tāmūr

Bibliography: Marteau and Vever, Miniatures persanes, vol. 2, pl. 59, no. 68 (13.160.8, the lion). Attribution: from "un livre d'histoire naturelle arabe," Timurid period, Persia, fifteenth century.

Pierpont Morgan Library, New York: two folios, three miniatures

M.790.1

recto: buffalo, gā $v$ mish

verso: ram, gusfand

M.790.2

recto: continuation of text on the ram and title of the goat, $b u z$

verso: miniature of the goat, $b u z$

Bibliography: B. Schmitz, Islamic and Indian Manuscripts and Paintings in the Pierpont Morgan Library (New York, 1997), cat. no. 13. Two miniatures illustrated: M.790.1 recto (buffalo) and M.790.1 verso (ram). Attribution: “probably Qazwin, ca. 1575-85." R. M. Riefstahl, An Exhibition of Persian and Indian Miniature Paintings from the Collections of Demotte, Inc. (New York, 1934), no. 25; $\mathrm{S}$. Ferber, Islam and the Medieval West, cat. of an exh. 


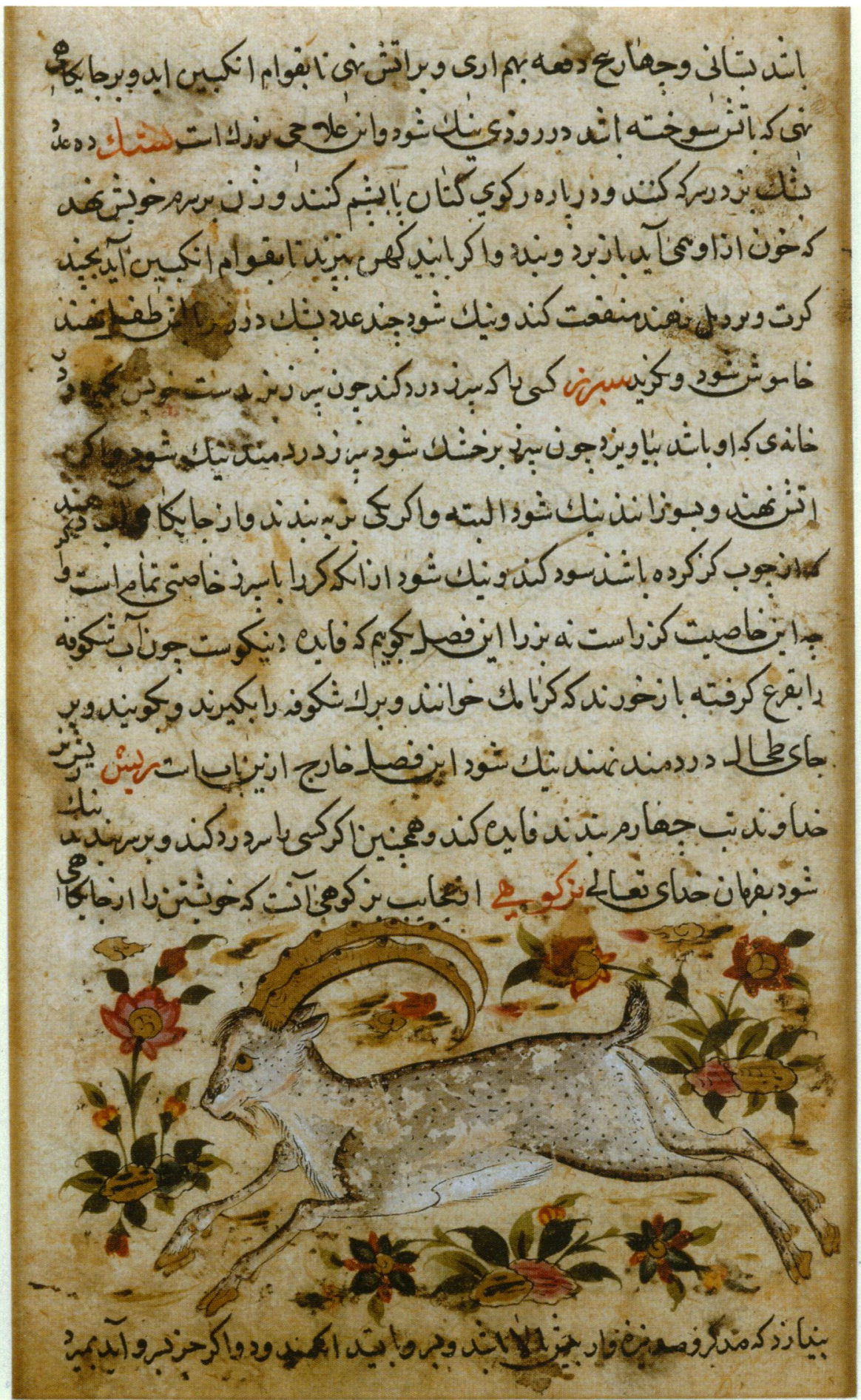

Fig. 9. Mountain goat (buz kūhì), from the dispersed Nuzhat-näma, Prince Sadruddin Aga Khan Collection, Ir. M. 16 (recto). Page 24.5 x $16.2 \mathrm{~cm}$, miniature 5.7 x $11.2 \mathrm{~cm}$. (Photo: courtesy of Prince Sadruddin Aga Khan Collection) 


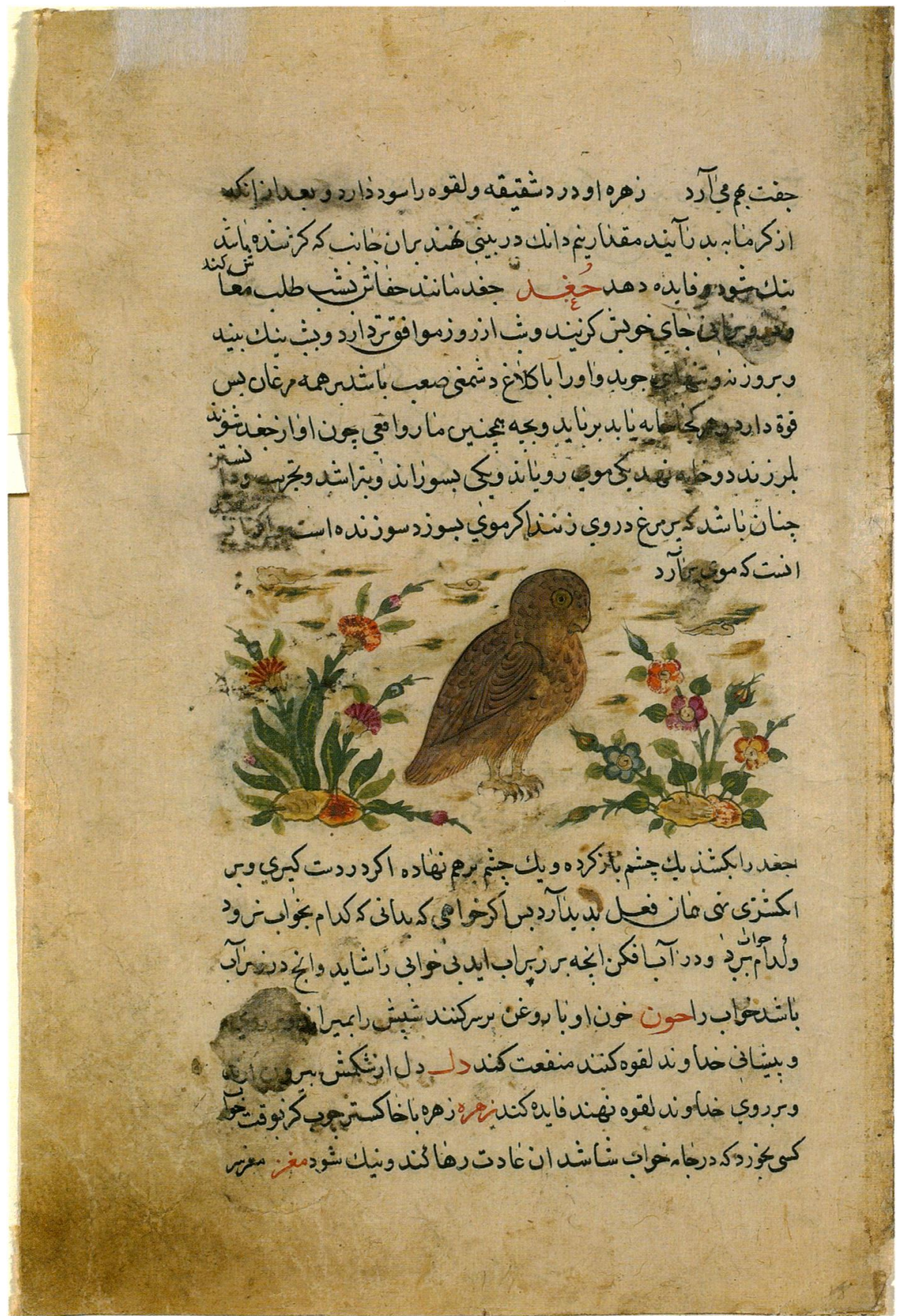

Fig. 10. Owl (jughd), from the dispersed Nuzhat-nāma, Prince Sadruddin Aga Khan Collection, Ir. M. 16/A (recto). Note the buds surrounded by spiky leaves. Page 24.5 x $16.2 \mathrm{~cm}$, miniature 5.5 x $10.5 \mathrm{~cm}$. (Photo: courtesy of Prince Sadruddin Aga Khan Collection) 


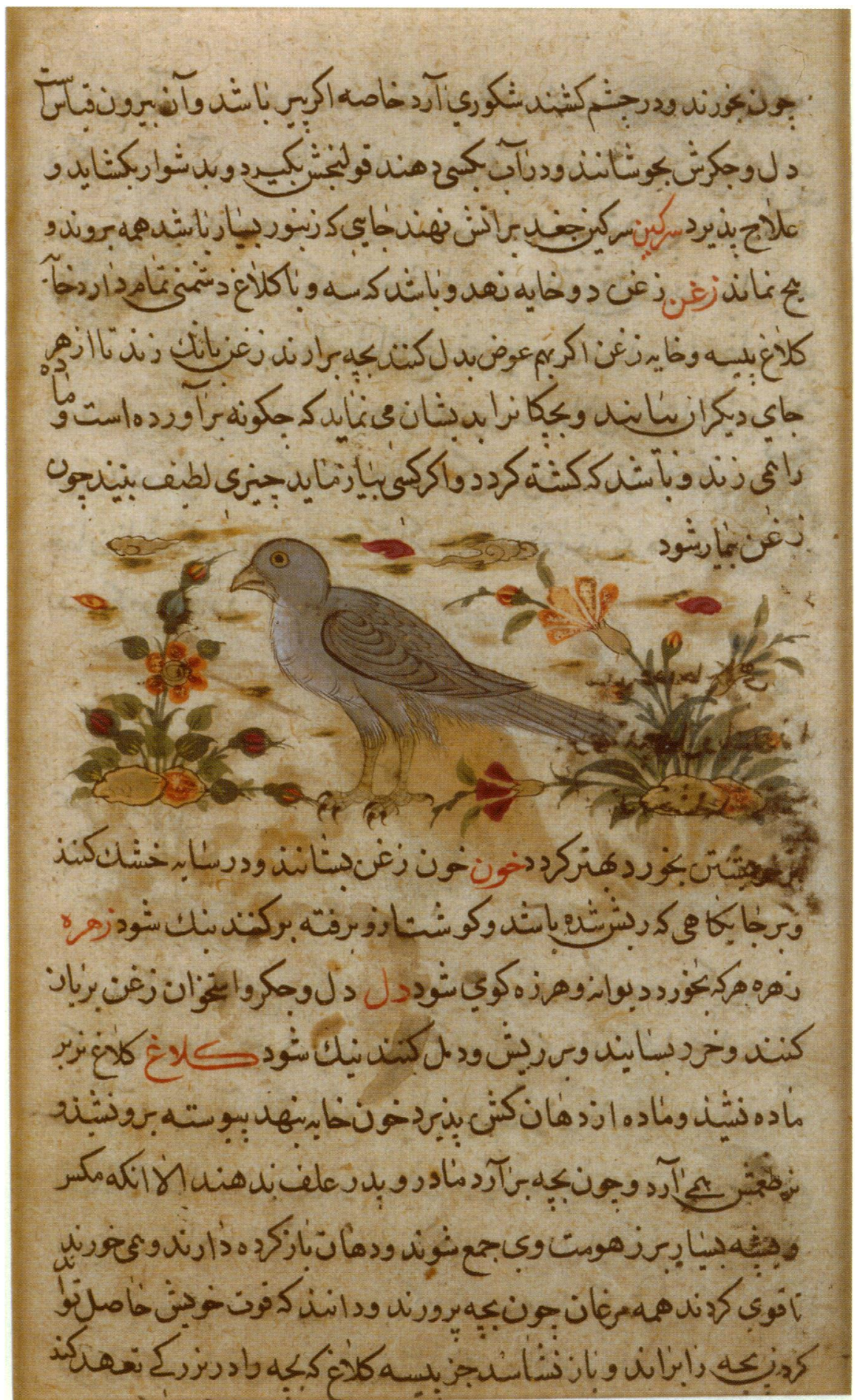

Fig. 11. Kite (zaghan), from the dispersed Nuzhat-nāma, Prince Sadruddin Aga Khan Collection, Ir. M. 16/A (verso). Miniature 4.5 x 10.7 cm. (Photo: courtesy of Prince Sadruddin Aga Khan Collection) 


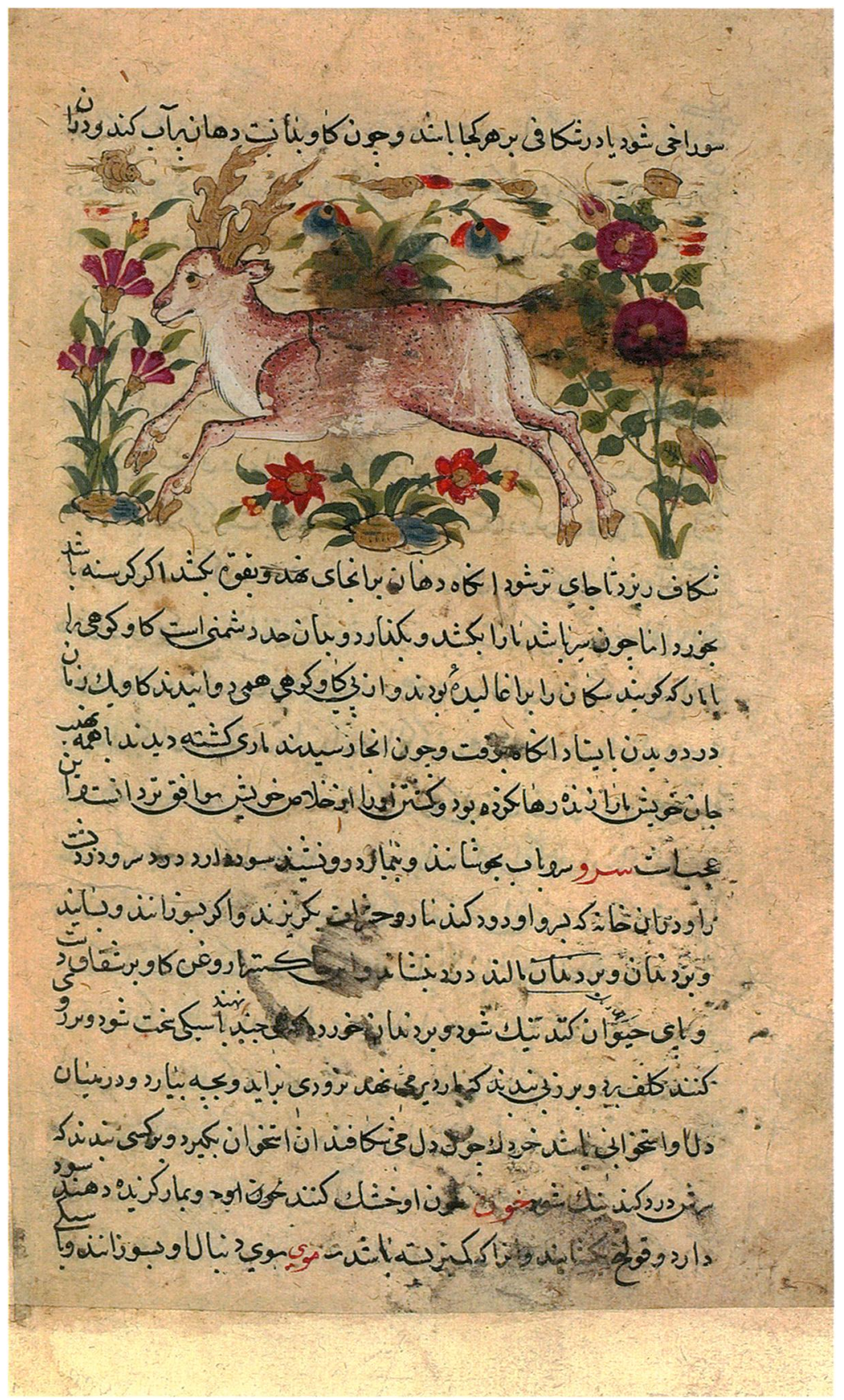

Fig. 12. Mountain cow/stag ( $g \bar{a} \bar{v} k \bar{u} h \bar{\imath})$, from the dispersed Nuzhat-nāma, Prince Sadruddin Aga Khan Collection, Ir. M. 16/B (verso). Page $24.5 \times 15.6 \mathrm{~cm}$, miniature $6.4 \times 10.8 \mathrm{~cm}$. Note the flying insect and butterfly in the upper right and left corners. (Photo: courtesy of Prince Sadruddin Aga Khan Collection) 


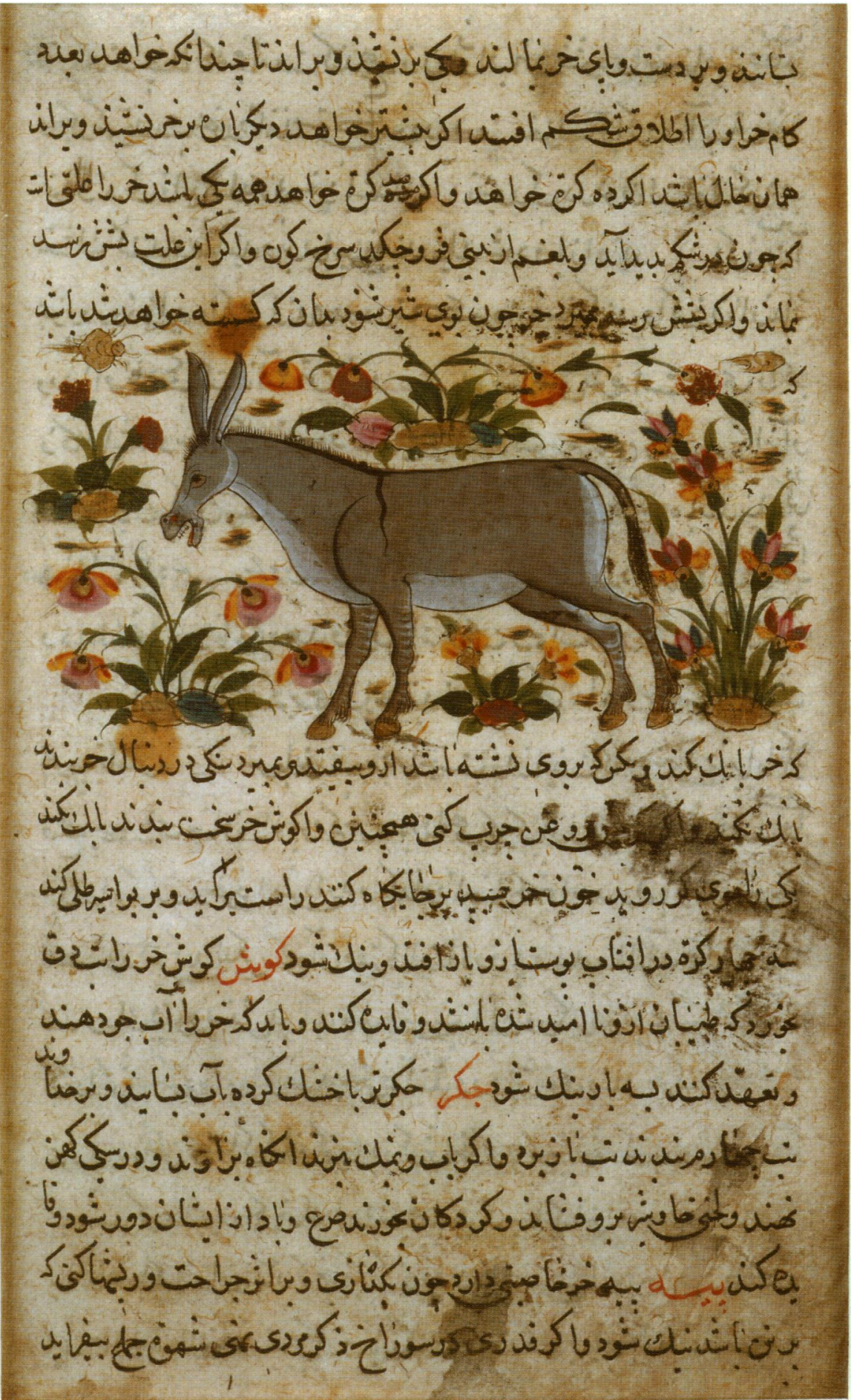

Fig. 13. Ass (khar), from the dispersed Nuzhat-näma, Prince Sadruddin Aga Khan Collection, Ir. M. 16/C (verso). Page 24.5 x $15.8 \mathrm{~cm}$, miniature $5.7 \times 10.7 \mathrm{~cm}$. Note the flying insect in the upper left corner. (Photo: courtesy of Prince Sadruddin Aga Khan Collection) 


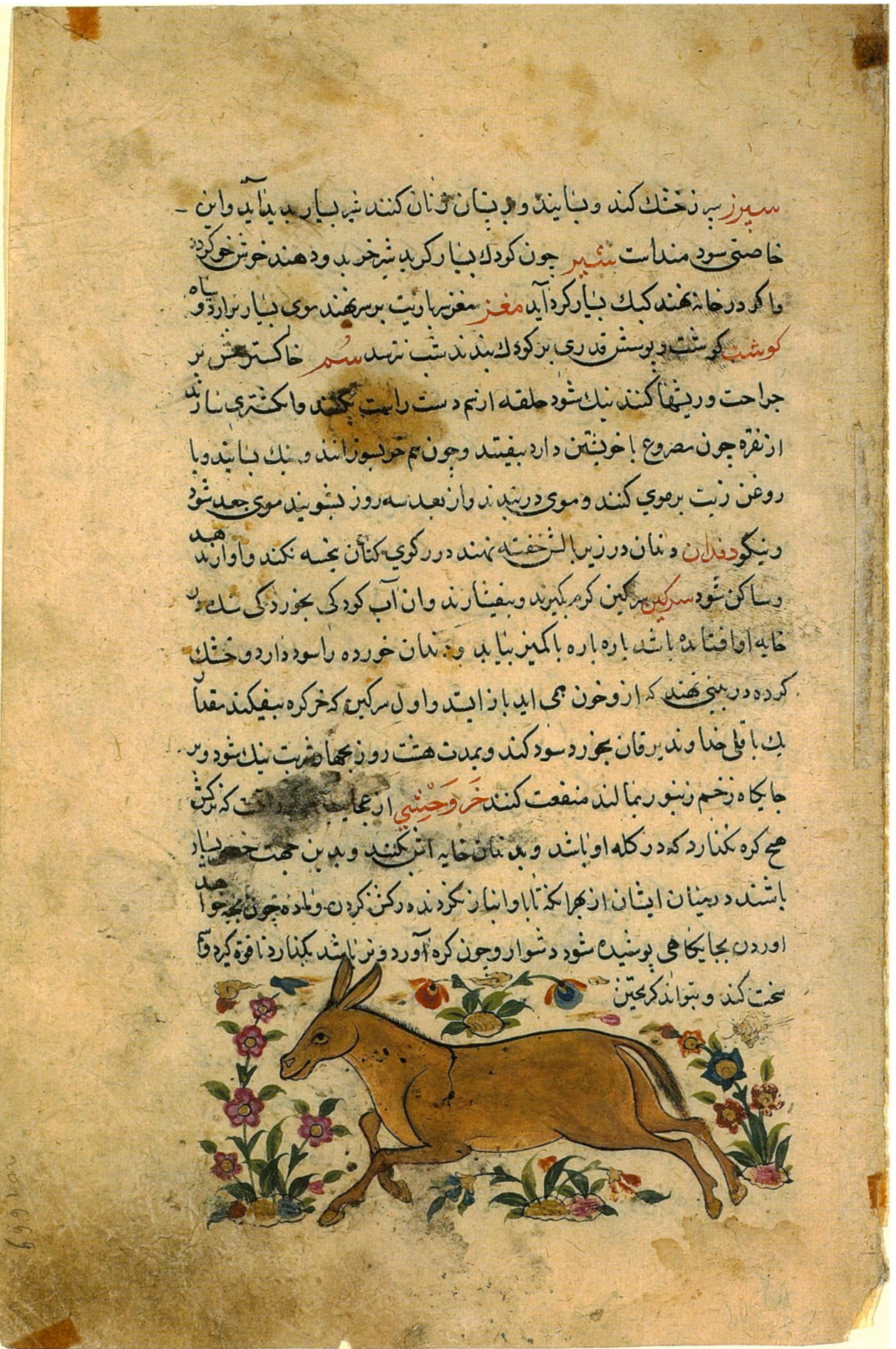

Fig. 14. Wild ass (khar-i vahshī), from the dispersed Nuzhat-nāma, Prince Sadruddin Aga Khan Collection, Ir. M. 16/D (recto). Page 24.5 x $16 \mathrm{~cm}$, miniature $5 \times 10.8 \mathrm{~cm}$. (Photo: courtesy of Prince Sadruddin Aga Khan Collection) 


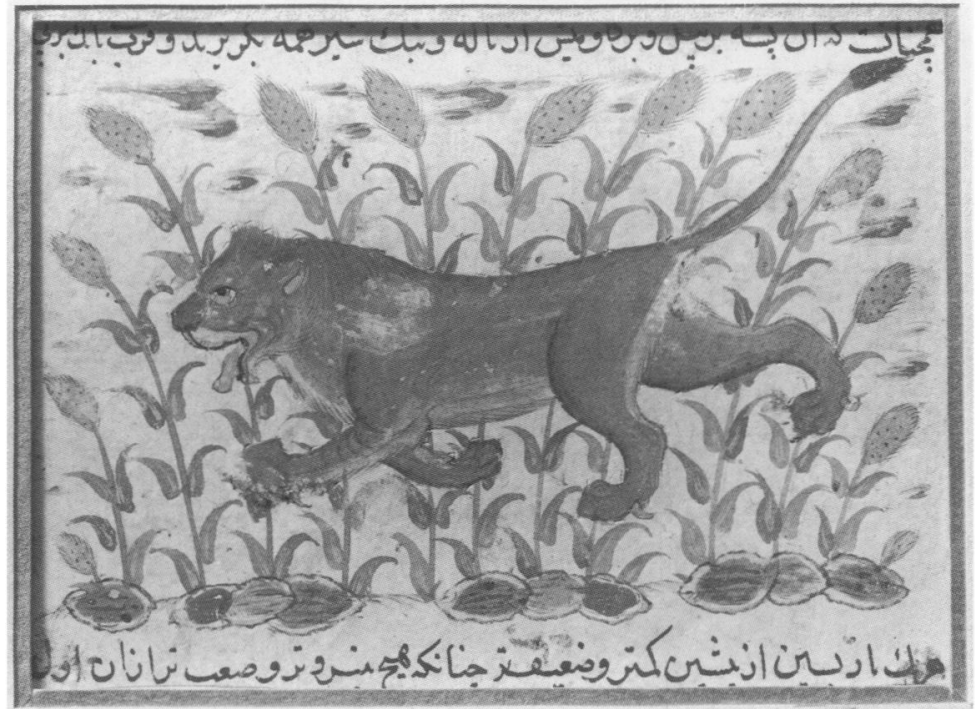

Fig. 15. Fragmentary folio, lion (shīr), from the dispersed Nuzhat-näma, Metropolitan Museum of Art, 13.160.8 (recto). Page 7.6 x $10.5 \mathrm{~cm}$. (Photo: courtesy of the Metropolitan Museum of Art, New York)

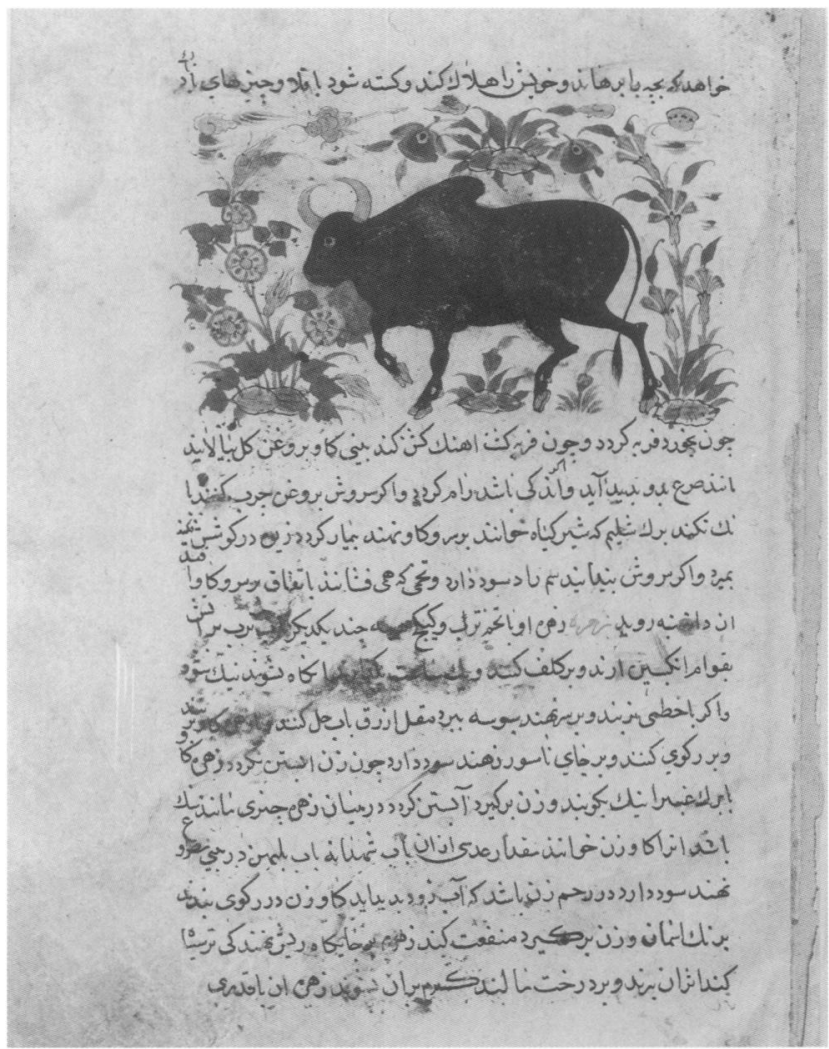

Fig. 16. Bull ( $g \bar{a} v$ ), from the dispersed Nuzhat-nāma, Metropolitan Museum of Art, 13.160 .7 (recto). Page $24.6 \times 16 \mathrm{~cm}$, miniature $6.3 \times 11 \mathrm{~cm}$. Note the flying insect and butterfly in the upper right and left corners. (Photo: courtesy of the Metropolitan Museum of Art, New York) 


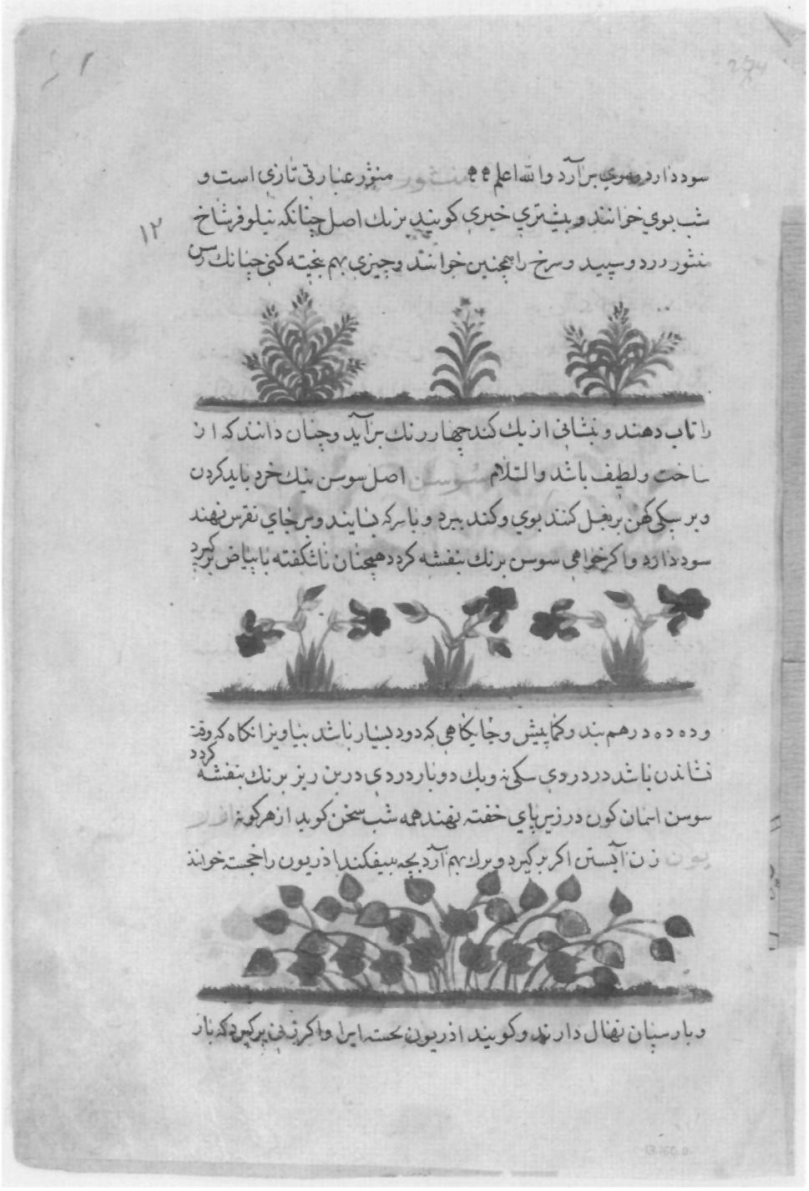

Fig. 17. Three plants: hesperis tristis (manșūr), iris (sūsan), and anemone (āzaryū $n$ ), from the dispersed Nuzhat-nāma, Metropolitan Museum of Art, 13.160 .9 (recto). Page $24.5 \times 16 \mathrm{~cm}$, miniatures $2.8 \times 10.5 \mathrm{~cm}, 2.8 \times 10.5 \mathrm{~cm}, 2.8 \times 10.7 \mathrm{~cm}$. (Photo: courtesy of the Metropolitan Museum of Art, New York)

at the University Art Gallery, Binghamton, NY, April 6-May 4, 1975 (Binghamton, NY, 1975), no. 82.

Museum of Fine Arts, Boston: two folios, three miniatures

\subsection{0}

recto: text on the tortoise and then title and text of the frog, bazagh; the frog not represented verso: title and miniature of the lizard, sūsmār

\subsection{1}

recto: ostrich, shuturmurgh

verso: crane, kulang

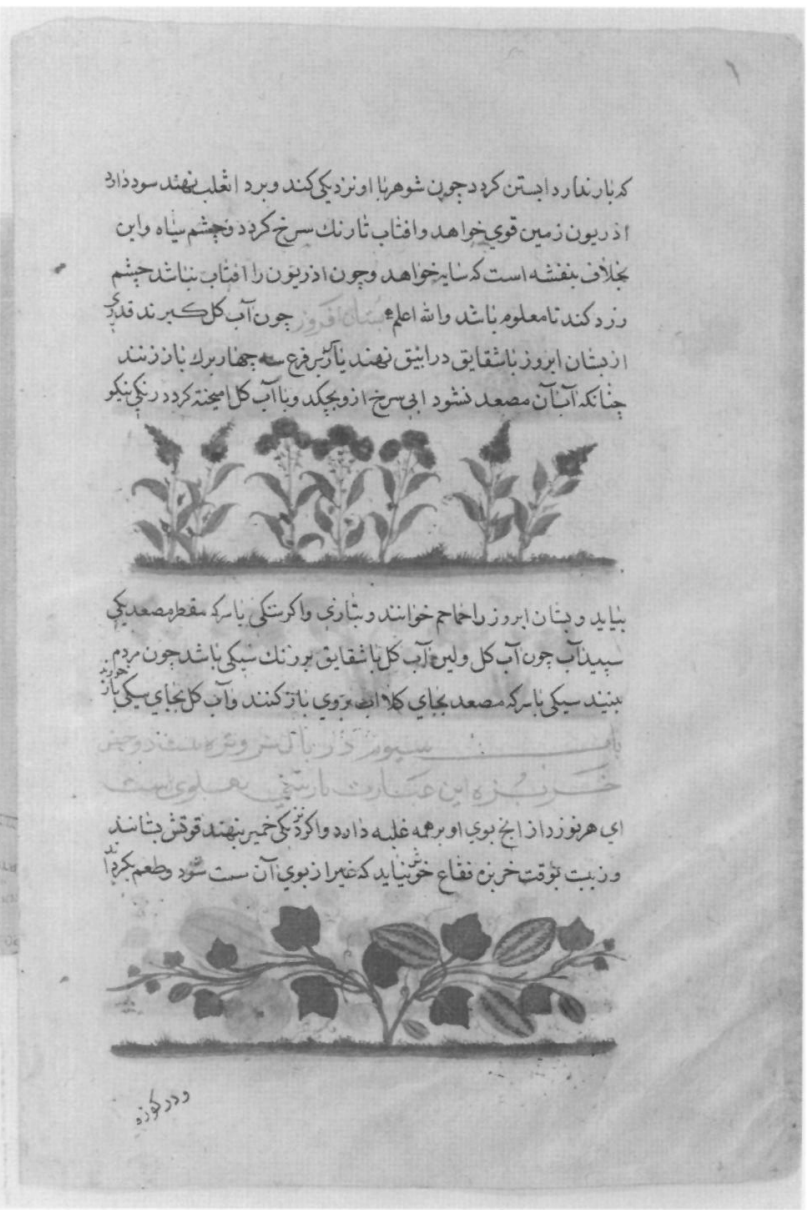

Fig. 18. Two plants: purple amaranth (bustān afrūz) and watermelon (kharbuza), from the dispersed Nuzhat-nāma, Metropolitan Museum of Art, 13.160 .9 (verso). Miniatures $3.5 \times 10.2 \mathrm{~cm}, 3.5$ $x 10.3 \mathrm{~cm}$. (Photo: courtesy of the Metropolitan Museum of Art, New York)

Bibliography: A. K. Coomaraswamy, Les Miniatures orientales de la collection Goloubew au Museum of Fine Arts de Boston (Paris, 1929), pls. 14 and 25a, b, and c (14.540 verso, lizard; 14.541 recto, ostrich; 14.541 verso, heron). Attribution: probably from a Manā $f^{c}$ al-hayawān, Persia, fifteenth or sixteenth century.

Collection of Jean Pozzi, Musée d'art et d'histoire, Geneva: two folios, four miniatures

Inv. 1971-107/496

recto: title and miniature of the chameleon, hirbā, then title of the scorpion, kazhdum verso: miniature of the scorpion, kazhdum 
Inv. $1971-107 / 423$

recto: miniature of the muskrat, fa'rat al-mushk verso: salamander, samandar

Bibliography: B. Robinson, L'Orient d'un collectionneur: Miniatures persanes, textiles, céramiques, orfèvrerie rassemblés par Jean Pozzi, cat. of an exh. at Musée Rath, Geneva, July 9-October 18, 1992 (Geneva, 1992), p. 128 and illustrations on p. 261. Three miniatures illustrated: inv. 1971-107/496 recto ("feline in a pool"); inv. 1971-107/ 496 verso ("scorpion"); inv. 1971-107/423 recto ("desert rat"). Attribution: from a Qazwini 'Ajä'ib al-makhlūqāt, Qazwin style (provincial), late sixteenth century.

\section{APPENDIX II: \\ THE PRESENT FOLIOS AND WHAT IS MISSING}

We thus have a total of nineteen folios with thirty-three miniatures. If the manuscript was originally complete, there must have been many other folios and miniatures, which, based on complete manuscripts such as those in the Gotha and Chester Beatty Libraries mentioned above, would have covered many more animals, plants, minerals, etc.

There are four miniatures among those published by Marteau and Vever of which the present whereabouts are unknown to me. ${ }^{38}$ The authors reproduce only the miniatures, not the whole pages; without the text, there is consequently no possibility of identification or of knowing whether the miniatures belong to separate folios. Represented are a trotting ass or onager among rocks and flowers; a group of birds on the branches of a bush or low tree; a bird with long plumage at the back; and vines with grape clusters on their branches, the trunks being sustained by slim columns with pediments and flat capitals that support a square, possibly wooden, structure through which the branching vines entwine. Only for this last miniature can we determine its place: it should be on a folio that is in sequence with (either preceding or following) the fragmentary one in the Freer (37.39 recto), which in fact deals with the grapevine (razangūr).

\section{Sequence of the present folios}

Several of the nineteen folios so far identified clump together into groups. The following list gives them in the order in which they occur within the edited text of the Nuzhat-nāma and indicates the number of subjects that intervene between them. The class of animals best represented is the quadrupeds. Following the first section (maqālat) of the first part (qism), on man, these make up the second section, and begin with the lion. This quadruped and twelve others are represented in the surviving miniatures, as follows:

Lion, shīr (Metropolitan Museum of Art, New York, henceforth MMA)

(Between this and the next folio are thirteen missing items.)

Ass, khar (Prince Sadruddin Aga Khan Collection, henceforth PSAK)

Wild Ass, khar-i vahshī (PSAK)

Bull, gãv (MMA)

Mountain cow, gā $k \bar{u} h \bar{\imath}$ (PSAK)

Buffalo, gā $v$ mish (Pierpont Morgan Library, New York, henceforth Morgan)

Ram, gusfand (Morgan)

Goat, buz (Morgan)

Mountain goat/ibex, buz $k \bar{u} h \bar{\imath}$ (PSAK) The text of this folio continues with the title and beginning of the account of the next entry, the camel, shutur, but with no miniature. There are then a further 14 missing items.

Muskrat, fa’rat mushk (Pozzi Collection, Musée d'art et d'histoire, Geneva, henceforth Pozzi)

Salamander, samandar (Pozzi)

(Three missing items)

Unicorn, jarish (MMA)

Steinbok, tāmūr (MMA)

(Three missing items)

The third section is devoted to birds, of which the first four are missing. We then have:

Ostrich, shuturmurgh (Museum of Fine Arts, Boston, henceforth Boston)

Crane, kulang (Boston)

Owl, jughd (PSAK)

Kite, zaghan (PSAK)

Crow, kalāgh (Harvard University Art Museums, Cambridge, MA, henceforth Harvard)

Peacock, $t \bar{a}^{\prime} u \bar{s}$ (Harvard)

(eight missing items)

Duck, murghā $b \bar{c}$ (Freer Gallery of Art, Washington, DC, henceforth Freer)

Pheasant, tazary (Freer) The text of this folio continues with the title and beginning of the account of the next entry, the swallow, khuttāf, but with no miniature. There are then a further five missing items.

The fourth section is devoted to reptiles and insects, of which the first twenty-two are missing. We then have: 
Final part of text on the tortoise, kashaf, followed by Frog, bazagh, neither illustrated (Boston)

Lizard, sūsmār (Boston)

(Two missing items)

Chameleon, hirbā (Pozzi)

Scorpion, kazhdum (Pozzi)

(Nineteen missing items)

The fifth section is devoted to plants and trees, with the surviving folios coming from the first three chapters $(b \bar{a} b)$. In the first chapter the first item is missing. We then have:

Text on the grapevine, razangūr, but with no miniature (Freer)

Apple tree, $s \bar{b} b$ (Freer)

(Six missing items)

Fig tree, anjīr (Freer)

Mulberry tree, $t \bar{u} d$ (Freer)

Olive tree, zaytūn (Freer)

(Four missing items)

In the second chapter the first six items are missing.

We then have:

Hesperis tristis, mans $\bar{u} r$ (MMA)

Iris, sūsan (MMA)

Anemone, àzaryūn (MMA)

Purple amaranth, bustān afrūz (MMA)

In the third chapter we have just the first of twentytwo items:

Watermelon, kharbuza (MMA)

\section{School of Oriental and African Studies \\ University of London}

\section{NOTES}

Author's note: I should like to thank all the colleagues and friends who have facilitated my research on these folios and discussed various issues related to the study of them. In particular I thank Gülru Necipoğlu, Mary McWilliams, and Jennifer Allen, who assisted me during my research on the folio in the Harvard University Art Museums. This folio was mounted so that its verso side was not visible, but it was dismounted while I was there so that I might have the opportunity to study it in its entirety. My thanks also go to Massumeh Farhad of the Freer Gallery of Art, Washington, DC; William Voelkle of the Pierpont Morgan Library in New York; Julia Bailey, formerly of the Museum of Fine Arts, Boston; Stefano Carboni of the Metropolitan Museum of Art, New York; Moya Carey and Diane Frascani for assistance on the folios in the Sadruddin Aga Khan Collection; Sandy Morton, with whom I had initially discussed problems of the sources of the Morgan Manāfi; Wheeler Thackston, with whom I discussed the text of the folios in Boston as well as other issues related to textual tradition and script; and Sunil Sharma, with whom I discussed at length the text of the folio at Harvard as well as the Nuzhat-nāma text in general. Finally, I am very grateful to Sheila Canby, of the British Museum, London, with whom I had interesting discussions about the style and possible date of these folios, and who has generously shared her knowledge of Safavid painting with me.

1. B. Schmitz, Islamic and Indian Manuscripts and Paintings in the Pierpont Morgan Library (New York, 1997), cat. no. 13.

2. I had already signaled this in "The Horse in Two Manuscripts of Ibn Bakhtīshūc's Kitāb Manāfic al-Hayawān," in Furusiyya: The Horse in the Art of the Near East, ed. D. Alexander (Riyad: The King Abdulaziz Public Library, 1996), 2 vols., vol. 1, pp. 14247 and color pls. III.I-III.VIII. The topic will be considered further in A. Contadini, A World of Beasts: Arab and Persian Books on Animals, Thirteenth to Fourteenth Centuries, forthcoming. For the Morgan Manāfí, see also Schmitz, Islamic and Indian Manuscripts, cat. no. 1.

3. E. Blochet, Catalogue of an Exhibition of Persian Paintings from the XIIth to the XVIIIth Cent. Formerly from the Collections of the Shahs of Persia and of the Great Moguls Held at the Galleries of Demotte, Inc. (New York, n.d. [1927]); R. M. Riefstahl, An Exhibition of Persian and Indian Miniature Paintings from the Collections of Demotte, Inc. (New York, 1934), no. 25: description of the folio with a ram and a buffalo, attributed in the catalogue to Tabriz, ca. 1480 (now in the Pierpont Morgan Library, New York, M.790.1).

4. G. Lazard, "Un amateur de sciences au Vème siècle de l'hégire, Shahmardân de Rai," in Mélanges d'orientalisme offerts à Henri Massé (Tehran, 1963), pp. 219-28. It is on this article that the present biographical paragraph is based.

5. Shahmardān b. Abī 'l-Khayr, Nuzhat-nāma-i 'Alä’̄', ed. Farhang Jāhānpur (Tehran, 1362/1984), henceforth Edition.

6. Manuscript Persian, no. 146: see W. Pertsch, Die Persischen Handschriften der Herzoglichen Bibliothek zu Gotha (Vienna, 1859), pp. 30-36.

7. Shahmardān, Edition, pp. 7-8. C. A. Storey, Persian Literature: A Bio-Bibliographical Survey (Leiden, 1977, first ed. 1927), vol. 2 , pt. 3, pp. 348-49. It may be added that he is also known as the author of the Rawdatu 'l-munajiminn (The Garden of the Astrologists), a detailed introduction to astrology for beginners. See Storey, Persian Literature, vol. 2, no. 81; J. Rypka, History of Iranian Literature (Dordrecht, 1968), p. 465.

8. Shahmardān, Edition, pp. 14-15. G. Weil, Geschichte der Chalifen, nach handschriftlichen, grösstentheils noch unbenützten Quellen bearb. (Mannheim: F. Bassermann, 1846-51), vol. 3, p. 85, n. 3; Pertsch, Die persischen Handschriften, p. 30.

9. E. de Zambaur, Manuel de généalogie et de chronologie pour l'histoire de l'Islam (Hannover, 1927), pp. 216-17, no. 208.

10. Storey, Persian Literature, vol. 2, pt. 3, pp. 348-49: "it must have been written after $475 / 1082-3$ (or $477 / 1084-5$ according to the text quoted in the Majlis catalogue, p. 492/9), since that is the date which he assigns (with a query) to an event witnessed by him at Kashan (Nuzhat nama, Maqalah X, Bab I, last fasl)."

11. See A. J. Arberry et al., The Chester Beatty Library: A Catalogue of the Persian Manuscripts and Miniatures (Dublin, 1959-62), 3 vols., vol. 1, p. 32 for the Nuzhat-nāma manuscript Per 115 (datable to ca. 1400).

12. Zabīhạalāh Sabā, Tārīkh-i adabiyyāt dar İrān, vol. 1 (Tehran, 1336/1958), p. 909.

13. G. Lazard, "Un amateur de sciences," pp. 219-28. A bald 1120 is given by Rypka, History of Iranian Literature, pp. 152-53, but 
without supporting evidence. Rypka does, however, usefully comment on an aspect of the work that will not be touched upon here: its inclusion of an epitome of the epic tradition derived from an earlier version by Piruzan; there were, Rypka says, "two prose summaries: the first...was collected by Rustam Lariyani...; the second was written by Piruzan, 'the teacher,' at the command of his Kakuyid Amir between 1040 and 1050 . About seventy years later Shahmardan reproduced Piruzan's version in abridged form in his Nuzhat-nama (1120)."

14. The conclusion that the Nuzhat-namma was to be dated early in the sixth century AH, and not later than 513 (1119), had already been reached by A. N. Compagnoni, "Hakim Esfazari," Université de Téhran, Revue de la Faculté des letters 5, 1-2 (Sept.-Dec. 1957): 166-230, pp. 182, 185 (Persian text).

15. Shahmardān, Edition, p. 8.

16. The other six sections deal with $(7)$ the elements, space, and time, etc. (8) arithmetic, astronomy, logic, astrology, seals, etc. (9) physiognomy (10) meteors (āsār-i 'ulvin) (11) dream interpretation (12) chemistry, dyeing, polishing, perfumes, etc. These are followed by a concluding anjām (on the creation of man, animals, and the soul). For two examples of illustrated Nuzhat-näma manuscripts that include parts of these sections, see New York Public Library, Spencer Ms. 50, in B. Schmitz, Islamic Manuscripts in The New York Public Librany (New York and Oxford, 1992), cat. no. II.3; and Chester Beatty Library, Per 255 , dated $1007 / 1599$ (but with illustrations possibly added at a later stage, ca. 1620), in Arberry, Chester Beatty Library, vol. 3, p. 31.

17. See A. Contadini, "The Ibn Buhtīshū ${ }^{c}$ Bestiary Tradition: The Text and Its Sources," in Medicina nei Secoli: Arte e Scienza 6, 2 (1994): 349-64.

18. Shahmardān, Edition, p. 136.

19. Ibn Bakhtīshū', Kitāb na t al-hayawàn, North Jazira(?), ca. 1220, London, British Library, Or. 2784. See A. Contadini, "The Kitāb na't al-hayawān (Book on the Characteristics of Animals), British Library, Or. 2784, and the "Ibn Bakhtīshū' Illustrated Bestiaries," PhD diss., SOAS, University of London (1992).

20. It is possible that the $\mathrm{Na}^{c} t$ also includes a use for the gallbladder, for there is one unnamed body part that is used, like the gallbladder in the Nuzhat-nāma, to treat laqwa, a form of facial paralysis. But if so that is as far as the resemblance goes, for the methods of preparation and treatment are different.

21. San Lorenzo del Escorial, Biblioteca Real, Ar. 898, fol. 79r. See A. Contadini, "The Kitāb manāfi al-hayawān in the Escorial Library," Islamir Art 3 (1988-89): 33-57.

22. $\rightarrow$ A. Contadini, "A Bestiary Tale: Text and Image of the Unicorn in the Kitāb na't al-hayawān (British Library, Or. 2784)," Muqarnas 20 (2003): 17-33, p. 19 and n. 26.

23. This can be found in the museum notes of the Freer Gallery.

24. In the Österreichische Nationalbibliothek in Vienna, MS Mixt. 324. See D. Duda, Die illuminierten Handschriften und Inkunabeln der Österreichischen Nationalbibliothek, Islamische Handschriften I,
Persische Handschriften, Österreichische Akademie der Wissenschaften (Vienna, 1983), 2 vols., pp. 160-70, figs. 211-12.

25. Dublin, Chester Beatty Library, Per 115 and Per 255 respectively. See Arberry, Chester Beatty Library, vol. 1, pp. 32-33 for Per 115, and vol. 3, p. 31 for Per 255. Although the manuscript is dated 1007 (1599), the miniatures seem to have been added at a later date, as they conform to a style associated with material of ca. 1620 .

26. The manuscript is in the collection of Prince Sadruddin Aga Khan, M. 40, and it has been suggested that Sadiqi Beg was the painter. See A. Welch, Artists for the Shah (New Haven and London, 1976), chap. 3, pp. 41-99 for Sadiqi Beg and in particular for the Anvār-i suhayli, color pl. 12, figs. 46, 49, and 5053.

27. Schmitz, Islamic and Indian Manuscripts, no. 13, p. 48, where the manuscript is wrongly dated 1485 and referred to as N.F. 153, rather than N.F. 155. For this manuscript (N.F. 155), see Duda, Die illuminierten Handschriften, pp. 76-82, figs. 102-6.

28. As, for example, in fol. 102r ("Majnun throws himself at his mother's feet"), from a copy of the Khamsa of Nizami of ca. 1470 in the Vever collection: see G. D. Lowry (with S. Nemazee), A Jeweler's Eye: Islamic Arts of the Book from the Vever Collection (Washington, DC: Smithsonian Institution, 1988), col. pl. 42, p. 147.

29. In some cases, however, there is a thin pinkish or reddish outline underneath.

30. See M. Shreve Simpson, Arab and Persian Painting in the Fogg Art Museum (Cambridge, MA, 1980), no. 21, p. 67.

31. Ibid., no. 33, p. 91.

32. Ryl Pers 3. See B. W. Robinson, Persian Paintings in the John Rylands Library (London, 1980), no. 1439.

33. Ms. 966: Ethé 876. See B. W. Robinson, Persian Paintings in the India Office Library (London, 1976), nos. 1005-67, in particular no. 1013.

34. Tinted drawing J.26.1. See Robinson, India Office Librany, no. 212.

35. D 143 in the Institute of Oriental Studies. See Y. A. Petrosian, ed., De Bagdad à Ispahan: manuscrits islamiques de la filiale de Saint-Pétersbourg de l'Institut d'études orientales, Académie des sciences de Russie, cat. of an exh. at the Musée du Petit Palais, Oct. 14, 1994-Jan. 8, 1995 (Milan, 1994), no. 49, pp. 228-37.

36. See, in particular, the irises on fol. 36r, lilies and butterfly on fol. 36v, and poppies on fol. 48r, reproduced in color in Petrosian, Bagdad à Ispahan, color pls. on pp. 231, 232, and 235 respectively.

37. See B. Moor and E. A. Rezvan, "Al-Qazwini's 'Aja' ib al-Makhluqat wa Ghara' ib al-Mawjudat: Manuscript D 370," in Manuscripta Orientalia 8, 4 (Dec. 2002): 38-68, p. 39. For other manuscripts produced in Baghdad under the Ottomans at the end of the sixteenth and in the early seventeenth century, see R. Milstein, Miniature Painting in Ottoman Baghdad (Costa Mesa, 1990).

38. Marteau and Vever, Miniatures persanes, vol. 2, pls. 67, 69, 70, 72. 